\title{
Default risk, state ownership and the cross-section of stock returns: evidence from China
}

\author{
Lanlan Liu' ${ }^{1}$ Dan Luo ${ }^{2}$. Liang Han ${ }^{2,3}$ \\ Published online: 1 November 2018 \\ (C) The Author(s) 2018
}

\begin{abstract}
We apply a structural model to estimate firm-level default risk in China and investigate the stock return predictability of default risk and the moderating effects of state ownership for the sample period from 2003 to 2015. We show unique evidence that in China, default risk is positively associated with expected stock returns and state ownership matters considerably to the return predictability of default risk. We find investors of state-owned enterprises are not compensated appropriately in China despite of their higher default risk exposure. Our empirical evidence supports the conjecture on shareholder advantages and suggests that a strong bargaining power of equity holders would have a negative impact on stock returns.
\end{abstract}

Keywords Chinese stock market $\cdot$ Default risk $\cdot$ Return predictability $\cdot$ State ownership

JEL Classification $\mathrm{G} 14 \cdot \mathrm{G} 15 \cdot \mathrm{C} 14$

Defaults in China's local public bond market are a relatively new phenomenon, and have picked up pace since the government allowed the first one in 2014. There were a record 29 defaults on publicly issued notes in 2016, and there have

Dan Luo

dan.luo@henley.ac.uk

Lanlan Liu

lanlanliu@nau.edu.cn

Liang Han

liang.han@henley.ac.uk

1 Institute of Economics and Finance, Nanjing Audit University, Nanjing 211815, China

2 Henley Business School, University of Reading, Reading RG6 6UD, UK

3 School of Accounting, Tianjin University of Finance and Accounting, 25 Zhujiang Road, Tianjin 300222, China 
been 13 this year [2017], according to data compiled by Bloomberg. (May 25 2017, Bloomberg)

\section{Introduction}

Recent corporate defaults of Chinese companies have drawn extensive media coverage and become 'a cautionary tale for investors' ${ }^{1}$ However, there has been little empirical investigation on the relationship between corporate default risks and expected stock returns in a Chinese setting. At the moment, most of the existing empirical studies have attempted to employ various measures of default risk and to examine the 'risk-return' relationship in developed markets, such as U.S. (e.g. Dichev 1998; Chava and Purnanandam 2010), Australia (e.g. Gharghori et al. 2009), and U.K. (e.g. Chen and Hill 2013). This paper, instead, aims to investigate the moderating effects of state-ownership on the 'default risk-stock return' relationship in a Chinese setting. This is particularly important for three reasons. First, empirical evidence on such a relationship has been inconclusive. On one hand, default risk has been found to be systematic and firms with greater default risk tend to return investors higher 'default risk premium' (e.g. Vassalou and Xing 2004). On the other, there has been empirical evidence on the negative relationship between default risk and future stock returns (e.g. Campbell et al. 2008). Such a 'distress puzzle' might be resulted from some of the firm-specific characteristics, such as high leverage and low profitability (Filipe et al. 2016).

Second, although several studies have evaluated the predictability of Chinese stock returns, results on the relationship between firm characteristics and stock returns are not in line with findings in other stock markets. For instance, Chen et al. (2010) test 18 return predictors and find that only 4 are significantly correlated with Chinese stock returns. In particular, predicting stock returns for Chinese SOEs is not easy due to their financial opacity and low informativeness of share prices (e.g. Lee and Wang 2017). Moreover, the relationship between corporate default risk and stock returns is rarely studied in the context of Chinese stock market. The evaluation of corporate default risk in China becomes particularly important when interest rate deregulation has intensified competition and a deterioration of the economic environment has increased the volatility and imposed higher default risks on highly leveraged firms. As a result, investors may require higher returns for bearing higher default risk. Nevertheless, the perceived riskiness of high default risk firms of Chinese SOEs may differ with respect to non-SOEs.

Third, the implications of state-ownership for equity valuation and required return of shareholders appear ambiguous. On one hand, because the controlling shareholder of SOEs is the government, managers of SOEs can be induced to pursue political objectives rather than maximize corporate profits, resulting in the expropriation of minority shareholders (e.g. Ben-Nasr et al. 2012; Lee and Wang 2017). One typical evidence of this would be the burst of Chinese SOEs' capital investment in real estate rather than productivity-enhancing corporate assets following financial crisis in response to central government's monetary stimulus, which leads to inefficient capital allocation (Deng et al. 2014). Additionally,

\footnotetext{
1 Wuyang Construction Group Co., for example, defaulted in August 2017 with a total of USD \$209 million (September 10, 2017, Bloomberg) and Moody's downgraded the nation's credit rating in May 2017 (May 25, 2017, Bloomberg) due to the concerns with the rising corporate debt and default.
} 
Huang (2016) finds such “Tunneling', phenomenon is prevalent among Chinese SOEs companies through the issuance of loan guarantees issued by listed firms to their relatedparties (RPLG). On the other hand, state-ownership has been perceived as a favorable signal of firm valuation. Du et al. (2016) find state-ownership has a positive and significant impact on Chinese acquirers' returns in cross-border mergers and acquisitions. Moreover, it is widely accepted that government serves as implicit and explicit guarantor on loans issued to SOEs (e.g. Faccio 2010; Song et al. 2011).

The benefits of government protection enjoyed by distressed SOEs may outweigh their costs of distress, reducing the required rates of return by investors. This is consistent with the 'shareholder advantage' mechanism proposed in Garlappi et al. (2008), where with a stronger bargaining power in debt renegotiation, shareholders of SOEs tend to have lower required risk premium for default risk exposure. In addition, research has found that connections with the government can reduce firm's exposure to systematic risk as well as cost of equity capital, especially in the event of financial distress (Boubakri et al. 2012). As a result, our key conjecture would be that state-ownership may affect the relationship between default risk and expected stock returns in China.

This paper aims to investigate the cross-sectional relation between default risk and stock returns by considering the unique features of Chinese stock markets, which is missing from existing literature. We commence our analysis by estimating the monthly default risk (default likelihood indicators, DLI) based on Merton's (1974) structural model for 213,173 firm-month observations between 2003 and 2015 and then examine the return predictability of default risk using portfolio sorts and cross-sectional regression approaches, with additional double sorting robustness tests. We document time and ownership variation of default risk and show that firms under Specially Treatment $(\mathrm{ST})^{2}$ and state-owned enterprises (SOEs) have higher default risk than their counterparts. In the empirical examination on the 'risk-return' relationship, we show that stock returns are positively and monotonically associated with default risk, with and without a CAPM framework to control for market risk. By double sorting on size and default risk (and state-ownership and default risk), we show consistent evidence that the positive 'risk-return' relationship exists among small and non-SOEs only. Such a finding is further supported by the results of Fama-Macbeth regressions where SOEs with higher default risk do not compensate investors with higher returns. In addition, our multivariate regression results show that firms which are smaller, less profitable, highly leveraged, having less growth opportunities, operating in real estate and industrial sector, and ST firms tend to expose to a greater default risk. Our empirical results suggest that the positive 'default risk-return' relationship does exist in Chinese stock markets but for small and non-SOEs only. The state-ownership mitigates such a relationship.

As far as we are aware, this is the first empirical study which comprehensively investigates the default risk exposure of companies publicly listed in China and its relationship with stock returns. We show novel evidence on the role played by state-ownership in mitigating the risk-return relationship and our empirical findings provide important implications to policy makers, creditors (e.g. banks) and investors. First, the increasing bank

\footnotetext{
${ }^{2}$ Chinese listed firms that have reported two consecutive annual losses (or whose book value becomes negative) are required to file for Specially Treatment (ST) status. The stock will be delisted if the firm reported four consecutive annual losses. The ST staus can be classified as ST, or *ST, or PT, which represents different levels of financial distress. ST stocks are under various trading and financial restrictions. For instance, the daily price fluctuation limit of such stocks is $5 \%$.
} 
non-performing loans (NPL) have been identified as a major concern for Chinese commercial banks and regulators should take more considerations on corporate default risks when controlling for banking sector risk exposure and to scrutinize corporate bond offering. Second, our results suggest that Chinese investors require a lower rate of return for investing in SOEs with high default risk, implying their beliefs that SOEs' debt burden is backed by an implicit government guarantee. This serves as a valuable basis for evaluating the moderating impact of institutional environment on asset prices.

The remainder of the paper is organized as follows. Section 2 describes the institutional background of Chinese stock markets. Section 3 discusses the empirical methods employed and variables used with a particular focus on the estimation of default risk exposure. Section 4 reports the empirical findings and Sect. 5 offers additional robustness tests. Finally, Sect. 6 concludes the paper.

\section{Institutional background of Chinese stock market and state-ownership}

Since the economic reform initiated in China in the late 1970s, financial institutions have been playing a critical role in financing businesses and supporting economic growth. As a milestone of the financial system reform, Shanghai Stock Exchange (SSE) and Shenzhen Stock Exchange (SZSE) were established in the early 1990s to facilitate the corporate ownership reform of SOEs and to improve the allocational efficiency of the Chinese financial markets. However, various restrictions imposed on stock issuing and trading, such as the A and B-share split, have led to market segmentation and high trading volatility (Groenewold et al. 2003). Meanwhile, the Special Treatment (ST) policy was initiated in 1998 to detect financially distressed firms and serves as an early warning signal to market participants. A ST firm will be either recovered via the removal of its special treatment or delisted in terms of its further performance.

SOEs have been playing an important role in the economic growth in China, such as being the key instruments in implementing government strategic plans. Therefore, with the development over nearly three decades, the stock markets in China are still characterized by a dominance of state-ownership and before 'Split Share Structure Reform' in 2005, for example, nearly two thirds of non-tradable shares in China were state-owned (Yang et al. 2015). ${ }^{3}$ Meanwhile, the practice of soft lending is common in China where large stateowned banks (SOBs) are required to provide consistent support to financially constrained SOEs, leading to increasing inefficiency in credit allocation (Cull and $\mathrm{Xu} \mathrm{2003,2005).}$ Hence, SOEs in China have superior access to financial markets compared with private firms on one hand, and they usually have lower operating efficiencies and are less profitable on the other (Fan et al. 2013).

The 'Split Share Structure Reform' was implemented in 2005 to improve the operating performance of SOEs and the overall efficiency of financial markets. Along with privatization reform, the ownership structure of Chinese listed companies has changed and both

\footnotetext{
3 The split share structure reform was launched in April 2005, with the aim to improve financial market liberalization. It is required that the shareholders of non-tradable shares should propose a plan for compensating tradable shareholders. Once the reform plan was approved by tradable shareholders, it was submitted to the China's Securities Regulatory Commission (CSRC). Then, the reform plan became effective after the CSRC's approval. By the end of 2007, 1260 firms have completed the reform process (Liao et al. 2014).
} 
the proportion of state-owned listed firms and state-ownership in percentage has declined significantly. Zeng and McLaren (2015) find a positive stock market reaction to the reform, indicating investors' belief about the economic gains associated with the reform. However, due to less formal institutional environment, the law enforcement on bankruptcy in transition economies like China is weaker than that of developed economies (Allen et al. 2005). In particular, Chinese government tends to restructure rather than liquidate financially distressed SOEs as majority of their creditors are SOBs, who are reluctant to write-off their balance sheets (Fan et al. 2013; Cull et al. 2015). This has therefore enabled financially distressed SOEs to receive continued financial supports from the SOBs. ${ }^{4}$

Despite the ongoing privatization reform, Chinese SOEs with weak fundamentals continue to receive implicit financial supports from the government. For instance, in 2017, the State-owned Assets Supervision and Administration Commission (SASAC) and the Ministry of Finance in China issued guidance for the disposal of 'zombie SOEs' that have suffered losses for three consecutive years. Consequently in the same year, more than ten listed SOEs announced that they received government subsidies for the disposal of "zombie SOEs”, with the amount ranging from RMB¥10 million to over RMB¥100 million. Such implicit guarantee of government bailouts in the event of financial distress would improve the likelihood that a firm recovers from distress. The average of recovery time (measured as the number of months from the time when a firm is specially treated to the removal of its ST status) for SOEs in our sample is 34 months, which is significantly short than the non-SOEs (45 months). ${ }^{5}$

\section{Methodology}

\subsection{Merton's structural model and default risk measurement}

Corporate default risk could be measured in different ways, such as by accounting-based models (Altman 1968; Ohlson 1980; Agarwal and Taffler 2008), hazard model (Campbell et al. 2008), credit risk ratings (Avramov et al. 2009), structural models (Vassalou and Xing 2004; Bharath and Shumway 2008) and credit ratings (Löffler 2013). In this paper, we employ a structural model to capture the default likelihood of Chinese companies. The structural models (e.g. Merton 1974), also known as contingent claim models, take firm's equity as a call option on its assets by following the option pricing theory (Black and Scholes 1973). In contrast to accounting-based models, structural models consider the time variance of default risk, i.e. the likelihood that the market value of assets drops below the face value of its liabilities, by deducting the market value and asset volatility from the simultaneous solution of equations. ${ }^{6}$ The validity of such models has been assured

\footnotetext{
${ }^{4}$ For instance, after the announcement of strategic restructuring of Bao Steel and Wuhan Steel in 2016, the China Construction Bank proposed a plan of \$3.6 Billion debt relief for Wuhan Steel.

5 Source: Author's own calculations.

${ }^{6}$ Since $1980 \mathrm{~s}$, Merton's structural model has been further developed by practitioners of KMV Corporation, currently known as Moody's KMV since the acquisition in 2002, by incorporating the empirical distribution of default probabilities where distance to default (DD) of each firm is captured in the first place and then the one-year Estimated Default Frequency (EDF) is derived based on KMV's extensive database of default events. Since then, additional default risk models have been developed, such as BSG-based contingent claims model (Hillegeist et al. 2004), discrete time hazard model (Campbell et al. 2008), cox proportional hazard model (Bharath and Shumway 2008), and etc.
} 
in various markets apart from the U.S., such as U.K. (Tudela and Young 2005), Japan (Xu and Zhang 2009), Australia (Gharghori et al. 2006), among others, and proved to be a valid model for forecasting corporate default probabilities. The advantages of structural models also lie in the usage of both observable driving variables and timely trading information from equity markets which is more informative and efficient than that from credit markets.

In Merton's structural model, the pay-offs to the equity holders are equivalent to the pay-offs of a call option holder on the value of a firm and the strike price of the call option is the face value of the firm's debt. Therefore, the value of the option would drop to zero once the value of the firm decreases to the strike price and the value of the call option increases with asset value as long as the asset value is greater than the debt value. Bankruptcy may happen when asset value is lower than the redemption value of debt. Assuming that the value of the firm $V_{A}$ follows a geometric Brownian motion process, the value of the firm at time $t$ would be:

$$
d V_{A t}=\mu V_{A t} d t+\sigma_{A} V_{A t} d W
$$

where $\mu$ is the mean rate of return on the firm's assets and $\sigma_{A}$ is the constant volatility of firm assets. Based on the option pricing function (Black and Scholes 1973), the value of the firm's equity (a European call) at time $t$ is given by:

$$
S_{t}\left(V_{A t}, \sigma_{A}\right)=N\left(d_{1}\right) V_{A t}-N\left(d_{2}\right) D_{t} e^{-r(T-t)}
$$

where $D_{t}$ is the book value of the firm's debt with a maturity date of T, $N\left(d_{1}\right)$ and $N\left(d_{2}\right)$ are risk-adjusted probabilities, and $r$ represents the risk-free interest rate. The values of $d_{1}$ and $d_{2}$ are defined as:

$$
d_{1}=\frac{1}{\sigma_{A} \sqrt{T-t}}\left[\ln \left(\frac{V_{A t}}{F_{t}}\right)+\left(r+\frac{\sigma_{A}^{2}}{2}\right)(T-t)\right] \quad \text { and } \quad d_{2}=d_{1}-\sigma_{A} \sqrt{T-t}
$$

Hence, a firm's default risk exposure could be inferred from the proximity of the total value of its assets to the total value of its debt. As long as the market value of assets and its volatility are available, default likelihood indicator (DLI hereafter), which captures the probability of debt value being greater than market asset value at the end of each period $\left(N\left(-d_{2}\right)\right)$, can be derived as:

$$
\mathrm{DLI}=\mathrm{P}\left(V_{A t}<D_{t}\right)=N\left(-d_{2}\right)=N\left[-\frac{\ln \left(\frac{V_{A t}}{F_{t}}\right)+\left(\mu-\frac{\sigma_{A}^{2}}{2}\right)(T-t)}{\sigma_{A} \sqrt{T-t}}\right]
$$

Empirically, we employ the iterative procedure to estimate monthly DLI of each firm. Details of this process are provided in the "Appendix 2".

\subsection{Cross-sectional regression}

We follow Fama and MacBeth (1973) and employ an across-sectional regression method to test the empirical validation and implications of Capital Asset Pricing Model (CAPM) by considering the roles played by firm specific characteristics in explaining cross-sectional differences in expected returns (e.g. Fama and French 2008; Campbell et al. 2008). In addition, we estimate adjusted standard errors by Newey-West procedure (Newey and West 
1987) to correct the bias of Fama-MacBeth model due to the heteroscedasticity and autocorrelation issues (Petersen 2009).

\section{Data and variables}

\subsection{Data}

Our empirical data are collected from the Chinese Stock Market and Accounting Research (CSMAR) database on companies publicly listed (A-shares) on either Shanghai Stock Exchange (SSE) or Shenzhen Stock Exchange (SZSE) in China between January 2003 and December 2015, excluding delisted and financial firms (Liao et al. 2014). ${ }^{7}$ Our final sample covers companies operating in industrials, real estate, commercials, utilities and others, with a nature of unbalanced panel with a maximum of 2010 firms in 2015 and a minimum of 976 firms in 2003. We collect daily and monthly stock returns and annual firm fundamental data for the empirical analysis.

In the following empirical analysis on the 'risk-return' relationship, our sample consists of 213,173 firm-month observations between 2003 and 2015. Although we primarily focus on the moderating effects of state ownership in market pricing of default risk, we run ST samples and all other samples separately in the empirical analysis because they face various trading and financial restrictions.

\subsection{Is DLI a valid measure of default risk?}

We employ Merton's structural model and measure monthly DLI using daily stock returns, market equity value, book asset value, short-term debt and long-term debt as key inputs. Table 1 reports the average DLI for the full sample and ST sample overtime, respectively, and shows that ST firms have greater DLI than those of the full sample. It also shows that the global financial crisis drove up DLI in Chinese stock markets ${ }^{8}$ to the highest level in 2008, suggesting that the default risk can be triggered either by idiosyncratic risks or by aggregate macroeconomic shocks (Hackbarth et al. 2006). The default risk of ST firms peaked in 2005 due to the accumulation of bad debts among the SOEs as well as the start of four state owned banks' privatization.

Prior studies on the evaluation of default risk prediction models focus on the predictive ability of models against corporate failures. Table 1 shows that the average DLI is much higher for firms in ST status than firms in normal status, indicating that DLI is capable of capturing financial distress of Chinese listed firms. When a listed firm is designated as ST and continues to make losses for two more years, it will be delisted form stock exchange. Thus, we identify failure firms as those have been publicly listed for at least two consecutive years and were delisted from the stock market (delisting for any reason) during the sample period from 2003 to 2015. In our sample, the average

\footnotetext{
7 Firm-level state ownership data is unavailable prior to 2003.

${ }^{8}$ For comparison purpose, we calculate DLIs for US firms by following the same approach. Figure 4 (Appendix) shows that the movement of DLIs in both countries became more strongly associated since financial crisis and the correlation coefficient increased from 0.39 overall to 0.78 since 2008, suggesting an increased integration among international financial markets and the rise of global systematic risk (Lehkonen 2014).
} 
Table 1 Descriptive statistics: DLI

\begin{tabular}{llrllr}
\hline Year & Full sample & \multicolumn{3}{l}{ ST firms } \\
\cline { 2 - 3 } \cline { 5 - 6 } & Number of stocks & DLI (bps) & & $\begin{array}{l}\text { Number of } \\
\text { stocks }\end{array}$ & DLI (bps) \\
\hline 2003 & 976 & 126.62 & & 78 & 212.82 \\
2004 & 1041 & 193.16 & & 56 & 349.11 \\
2005 & 1110 & 576.03 & & 50 & 916.79 \\
2006 & 1208 & 148.17 & & 82 & 256.74 \\
2007 & 1207 & 26.15 & & 73 & 48.57 \\
2008 & 1271 & 676.67 & 33 & 734.93 \\
2009 & 1398 & 357.91 & & 48 & 448.55 \\
2010 & 1451 & 46.59 & & 61 & 71.67 \\
2011 & 1544 & 47.67 & & 27 & 62.92 \\
2012 & 1768 & 133.12 & 37 & 236.96 \\
2013 & 1916 & 44.80 & 37 & 97.46 \\
2014 & 1985 & 34.32 & 35 & 83.33 \\
2015 & 2010 & 30.78 & 44 & 40.76 \\
\hline
\end{tabular}

This table reports the average number of stocks and average default likelihood indicator (DLI), in basis points between 2003 and 2015. The full sample includes all nonfinancial A-shares, and the ST samples include stocks of firms that are designated as ST, ST* or PT status in each year. The annual DLI is the arithmetic average of monthly default likelihood across firms

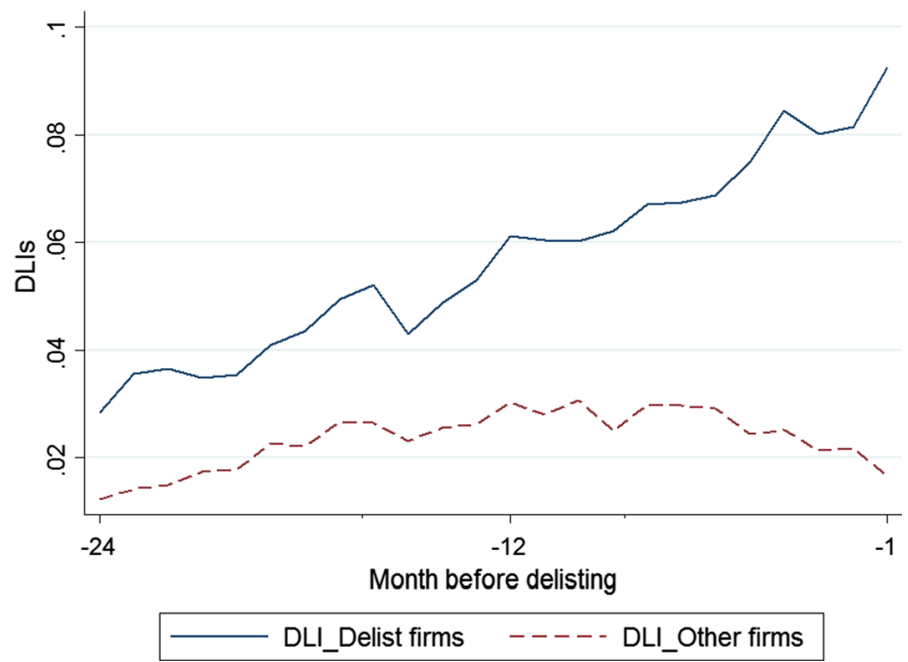

Fig. 1 DLI of Chinese delisted firms prior to delisting. This figure plots the monthly average default probability (DLI) of delist firms and other listed firms in normal status. The delisted sample includes all firms that were delisted from 2003 to 2015. DLI_delist firms is calculated as the monthly average DLI over 24-month prior to delisting across the delist sample. For each delisted firm $i$, we calculate the monthly average DLI across the full sample excluding $i$ over the 24-month period. Thus, DLI_other firms in each month $[-24,-1]$ is calculated as the average of those mean DLIs 
Table 2 Descriptive statistics: DLI over state-ownership

\begin{tabular}{lcccccc}
\hline & Obs & Mean & Median & \multicolumn{1}{c}{ P75 } & S.D. & Skewness \\
\hline $\begin{array}{l}\text { Panel A By state-ownership percentage } \\
\text { Zero SO }\end{array}$ & & & & & \\
Low SO $(0<$ SO $\leq 50 \%)$ & 67,306 & 234.29 & 1.11 & 84.74 & 678.02 & 6.08 \\
High SO $(\mathrm{SO}>50 \%)$ & 25,953 & 246.70 & 3.70 & 170.59 & 576.54 & 4.86 \\
$\begin{array}{l}\text { Panel B By ultimate controlling shareholder } \\
\text { Non SOEs }\end{array}$ & 89,850 & 154.53 & 0.15 & 23.62 & 545.46 & 7.85 \\
SOEs & 125,122 & 180.81 & 0.73 & 53.68 & 541.22 & 6.34 \\
\hline
\end{tabular}

This table reports summary statistics of default likelihood indicator (DLI, bps) over state-ownership (SO). In Panel A, samples are categorized into groups without (Zero SO), low $(0<\mathrm{SO} \leq 50 \%)$ and high (SO $>50 \%)$ state-ownership, respectively. In Panel B, a sample firm is classified as a SOE if its ultimate controlling shareholder is the state. Median and P75 represent the 50th, and 75th percentiles of DLI, respectively

DLI for 73 delisted firm over 12-month (or 24-month) prior to delisting are $717.16 \mathrm{bps}$ (567.56 bps), and is almost two times larger than the average DLI for other firms (as shown in Fig. 1). Figure 1 also clearly shows that the probabilities of default continuously increase during 24 months before the delisting. As such, our DLI variable constitutes a valid ex ante measure of corporate default risk.

\subsection{Other variables}

To capture the cross-sectional heterogeneity in expected stock returns at firm level, we follow Fama and French (2008) and Gharghori et al. (2009) to investigate firm characteristics including firm size $(M V)$, book-to-market ratio $(B / M)$, past returns $(M O M)$, leverage (leverage), profitability (profitability), capital expenditure $(C A P X)$ and their relationship with default risk. Following Liao et al. (2014), we employ two alternative measures of ownership structure, i.e. state-ownership $(S O)$ which is the ratio of stateowned shares to total shares outstanding and a dummy $(S O E)$ which is coded as 1 if the ultimate controlling party of a sample firm is state. We report variable construction in Table 12 (Appendix).

Table 2 documents the variation of DLIs over state-ownership which is measured by either the percentage of state share-holding (SO) or ultimate controlling party (SOE vs. non SOE). Overall, our descriptive statistics shows that DLIs increase over state-ownership, consistent with the evidence of Law and Roache (2015).

Table 3 reports the correlation matrix for the key variables and shows that firm default risk (DLI) is negatively correlated with firm size, $\mathrm{B} / \mathrm{M}$ ratio, profitability and investment (CAPX), and positively correlated with leverage ratio, consistent with existing evidence (e.g. Vassalou and Xing 2004; Bhattacharjee and Han 2014; Law and Roache 2015; Filipe et al. 2016). The correlations between DLI and expected returns are positive for the full sample, but the magnitude of coefficient becomes much smaller for samples with high state-ownership and SOEs, partially supporting our conjecture that government protection over SOEs may have been well recognized by investors. Even facing financial distress, state-backed shareholders would have a much stronger bargaining power compared with their counterparts in non SOEs (Fan et al. 2013). 
Table 3 Correlation matrix

\begin{tabular}{|c|c|c|c|c|c|c|c|}
\hline \multicolumn{2}{|c|}{ Variable } & 1 & 2 & 3 & 4 & 5 & 6 \\
\hline \multicolumn{8}{|c|}{ Panel A Full sample } \\
\hline 1 & DLI & 1 & & & & & \\
\hline 2 & Return & $0.031^{*}$ & 1 & & & & \\
\hline 3 & MV & $-0.240 *$ & $-0.037 *$ & 1 & & & \\
\hline 4 & $\mathrm{BM}$ & $-0.181^{*}$ & $0.017 *$ & $-0.183^{*}$ & 1 & & \\
\hline 5 & Profitability & $-0.106^{*}$ & $-0.021 *$ & $0.255^{*}$ & $-0.124 *$ & 1 & \\
\hline 6 & CAPX & $-0.015^{*}$ & -0.009 & $0.047 *$ & $0.087^{*}$ & $0.301 *$ & 1 \\
\hline 7 & Leverage & $0.241^{*}$ & 0.006 & $0.033 *$ & $-0.114^{*}$ & $-0.113^{*}$ & $-0.178 *$ \\
\hline \multicolumn{8}{|c|}{ Panel B High SO firms (SO>50\%) } \\
\hline 1 & DLI & 1 & & & & & \\
\hline 2 & Return & 0.007 & 1 & & & & \\
\hline 3 & MV & $-0.166^{*}$ & $-0.021^{*}$ & 1 & & & \\
\hline 4 & $\mathrm{BM}$ & $-0.127^{*}$ & 0.011 & $-0.108^{*}$ & 1 & & \\
\hline 5 & Profitability & $-0.141^{*}$ & $-0.013^{*}$ & $0.305^{*}$ & $-0.138 *$ & 1 & \\
\hline 6 & CAPX & $-0.175^{*}$ & 0.007 & $0.204^{*}$ & $0.128 *$ & $0.368^{*}$ & 1 \\
\hline 7 & Leverage & $0.287 *$ & $0.017 *$ & $0.048^{*}$ & $-0.113^{*}$ & $-0.134 *$ & $-0.072 *$ \\
\hline \multicolumn{8}{|c|}{ Panel C SOEs } \\
\hline 1 & DLI & 1 & & & & & \\
\hline 2 & Return & $0.010^{*}$ & 1 & & & & \\
\hline 3 & MV & $-0.175^{*}$ & $-0.018 *$ & 1 & & & \\
\hline 4 & $\mathrm{BM}$ & $-0.139 *$ & 0.009 & $-0.132 *$ & 1 & & \\
\hline 5 & Profitability & $-0.171^{*}$ & $-0.015^{*}$ & $0.218 *$ & $-0.417 *$ & 1 & \\
\hline 6 & CAPX & $-0.183^{*}$ & 0.011 & $0.093 *$ & $0.092 *$ & $0.131^{*}$ & 1 \\
\hline 7 & Leverage & $0.264^{*}$ & $0.016^{*}$ & $0.062^{*}$ & $-0.104^{*}$ & $0.149^{*}$ & $-0.076^{*}$ \\
\hline
\end{tabular}

This table reports the time-series average of monthly cross-sectional correlations between DLI and other variables, covering the period between 2003 and 2015. Details of variable constructions are provided in the Appendix (Table 12). Panels A, B and C present the correlations for the full sample, samples where the state-ownership (SO) is higher than $50 \%$ and state-owned enterprises (SOEs), respectively

*Denotes a statistical significant level of $5 \%$

\subsection{Default risk prediction}

In this section, we aim to examine whether default probabilities $\left(\mathrm{DLI}_{t}\right)$ of Chinese listed firms are related to firm fundamentals, such as state-ownership $\left(\mathrm{SO}_{t-1}\right)$. We perform Fama-Macbeth regression and adjust for within-cluster autocorrelations clustered by firm and report the results in Table 4.

Table 4 shows that the percentage of state-ownership $\left(\mathrm{SO}_{t-1}\right)$ is positively and significantly correlated with DLI in all models estimated. This is consistent with our conjecture and suggests that state-ownership is likely to lead to a higher default probability, all else equal. This result is similar to the findings in Law and Roache (2015), that the probabilities of default for central SOEs are higher than local SOEs.

Signs on the coefficients of other control variables are similar to those reported in the correlation matrix (Table 2), showing that firms which are smaller, less profitable, highly leveraged and with less growth opportunities are more likely to have greater default risk. 


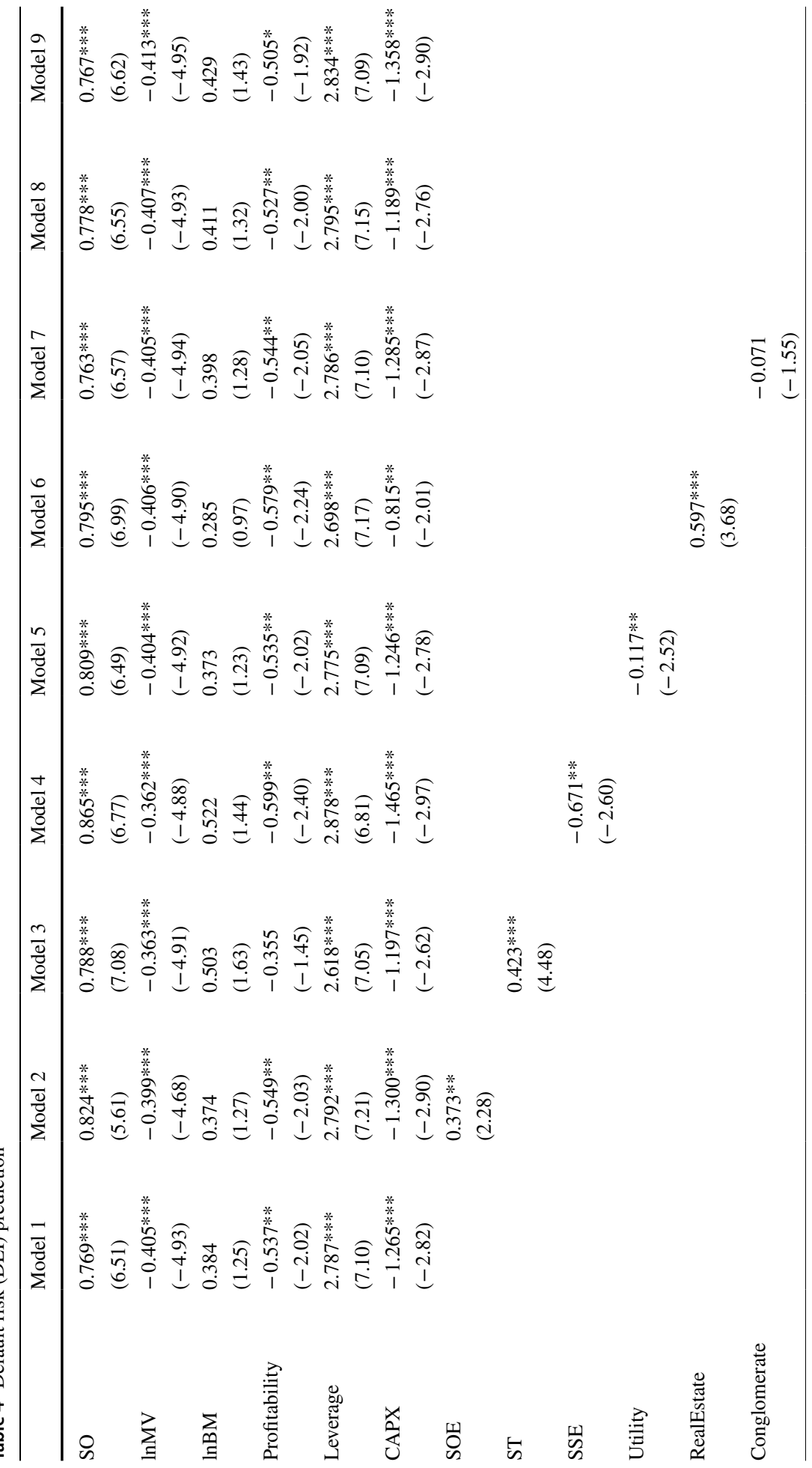




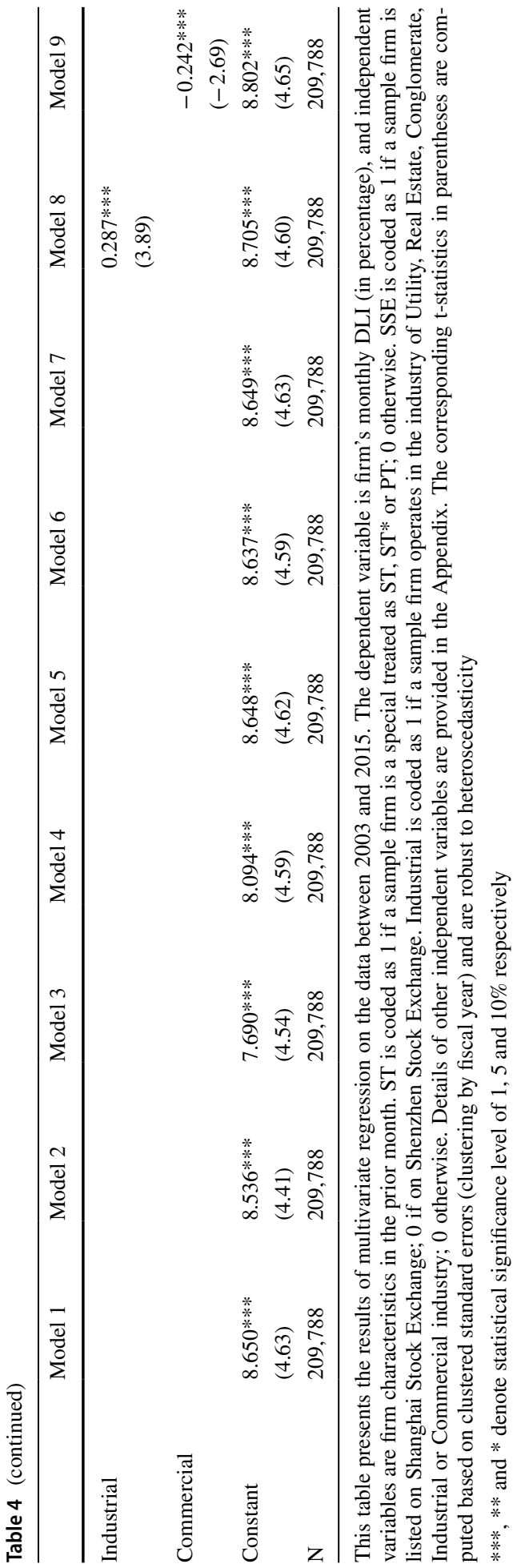


Moreover, given the different nature ${ }^{9}$ of firms listed on the two stock exchanges in China, the negative and statistically significant coefficient of the SSE dummy variable suggests that on average, stocks listed on SSE are subject to lower default risks. In terms of the systematic industry effect on firms' default risk exposure, firms operating in real estate sector (Model 6) and industrial sector (Model 8) are detected of having a higher default probability. This is consistent with expectations that excessive government-oriented investments over past decades and the higher leverage nature of the two industries have resulted to higher default probability of firms operating in the sectors. In general, results in Table 4 are consistent with findings in Vassalou and Xing (2004) and Altman et al. (2017), which discuss the link between default probabilities or financial distress and firm-specific characteristics in the U.S. market and find that firm size, profitability, liquidity and age are significantly correlated with default risk.

\section{Pricing of default risk}

This paper aims to investigate the relationship between default risk and expected stock returns in a Chinese setting by considering the moderating effects of state-ownership. We commence the empirical analysis using univariate tests to document the portfolio return variations over default risk and firm level controls. Then, we run Fama-MacBeth crosssectional regressions to investigate the 'risk-return' relationship and a multivariate analysis on the relationship between default risk and firm fundamentals. Finally, we run a set of additional regressions to test the robustness of our empirical results.

\subsection{Portfolio analysis}

Before running regression analysis, we examine if corporate fundamentals and returns vary over default risk exposure by employing a portfolio sorting approach which is less sensitive to outliers as it considers the idiosyncratic return co-movements. At the end of each month over the sample period, all firms are ranked based on their DLIs, and then are assigned to one of the five quintiles. Portfolios 1 and 5 denote group of firms with the lowest and highest default possibility, respectively. Portfolios are held for 1-month, and are rebalanced at the end of each month based on newly estimated default likelihood.

We merge monthly stock returns with the prior month's default likelihood indicator (DLI) to examine whether patterns in expected stock returns is related to default risk. Following Fama and French (1993), we retain a gap of 5-month between accounting data and stock return data to ensure that the accounting information is publicly available to investors before portfolio construction.

Panel A of Table 5 reports the variation of firm characteristics of five portfolios with ranked DLIs in quintiles. Apart from market value (MV) which is estimated as the timeseries averages of monthly cross-sectional means, ${ }^{10}$ other firm characteristics are the

\footnotetext{
9 Shanghai Stock Exchange (SSE) is significantly different from Shenzhen Stock Exchange (SZSE) in terms of market microstructure, especially in their listing requirements (Qiao et al. 2008). This is somewhat similar to the difference between the NYSE and NASDAQ stock exchanges in US. As compared with SSE, firms listed on SZSE are much smaller, less liquid and more volatile.

10 The distribution of firm size is highly skewed. The results will be driven by extreme large size numbers if averages of means are used.
} 
Table 5 Performance of default risk portfolios

\begin{tabular}{|c|c|c|c|c|c|c|c|}
\hline Portfolio DLI & Low (1) & 2 & 3 & 4 & High (5) & $\mathrm{H}-\mathrm{L}$ & $t$ \\
\hline \multicolumn{8}{|l|}{ Panel A Firm characteristics } \\
\hline DLI (bps) & 11.28 & 47.48 & 93.06 & 171.47 & 607.88 & 596.60 & $(9.06)$ \\
\hline MV (Million) & 5168.1 & 4297.8 & 3983.2 & 3937.9 & 4214.9 & -953.2 & $(-6.23)$ \\
\hline $\mathrm{BM}$ & 0.37 & 0.44 & 0.46 & 0.46 & 0.44 & 0.07 & $(9.87)$ \\
\hline TA (Million) & 6395.3 & 5903.6 & 6499.8 & 8092.0 & $12,089.4$ & 5694.1 & $(7.26)$ \\
\hline Profitability & 0.09 & 0.07 & 0.06 & 0.04 & 0.03 & -0.06 & $(-12.31)$ \\
\hline CAPX & 0.06 & 0.06 & 0.05 & 0.05 & 0.04 & 0.02 & $(4.25)$ \\
\hline Leverage & 0.37 & 0.46 & 0.51 & 0.56 & 0.61 & 0.24 & $(56.83)$ \\
\hline $\mathrm{SO}(\%)$ & 16.47 & 16.52 & 16.72 & 16.88 & 18.27 & 1.80 & $(5.60)$ \\
\hline Asset volatility & 0.37 & 0.36 & 0.35 & 0.36 & 0.44 & 0.07 & $(13.39)$ \\
\hline Distance to default (DTD_CRI) & 6.29 & 4.67 & 4.02 & 3.55 & 3.12 & -3.17 & $(-39.08)$ \\
\hline Z-score & 1.09 & 0.99 & 0.92 & 0.86 & 0.74 & -0.35 & $(-15.52)$ \\
\hline \multicolumn{8}{|c|}{ Panel B Raw returns of DLI portfolio } \\
\hline Equal-weighted (EW) & $\begin{array}{l}1.822 * * \\
(2.31)\end{array}$ & $\begin{array}{l}1.961 * * \\
(2.36)\end{array}$ & $\begin{array}{l}2.067 * * \\
(2.42)\end{array}$ & $\begin{array}{l}2.237 * * \\
(2.56)\end{array}$ & $\begin{array}{l}2.402 * * * \\
(2.68)\end{array}$ & $0.579 * * *$ & $(2.60)$ \\
\hline Value-weighted (VW) & $\begin{array}{l}1.351^{*} \\
(1.87)\end{array}$ & $\begin{array}{l}1.571 * * \\
(2.02)\end{array}$ & $\begin{array}{l}1.547^{*} \\
(1.91)\end{array}$ & $\begin{array}{l}1.681 * * \\
(2.04)\end{array}$ & $\begin{array}{l}1.826 * * \\
(2.18)\end{array}$ & $0.475 * *$ & $(2.15)$ \\
\hline \multicolumn{8}{|c|}{ Panel C. CAPM alphas of DLI portfolio } \\
\hline Equal-weighted (EW) & $\begin{array}{l}0.581 \\
(1.41)\end{array}$ & $\begin{array}{l}0.663 \\
(1.52)\end{array}$ & $\begin{array}{l}0.757 \\
(1.65)\end{array}$ & $\begin{array}{l}0.909 * \\
(1.88)\end{array}$ & $\begin{array}{l}1.083 * * \\
(2.14)\end{array}$ & $0.502 * *$ & $(2.25)$ \\
\hline Value-weighted (VW) & $\begin{array}{l}0.148 \\
(0.47)\end{array}$ & $\begin{array}{l}0.279 \\
(0.86)\end{array}$ & $\begin{array}{l}0.230 \\
(0.63)\end{array}$ & $\begin{array}{l}0.353 \\
(1.25)\end{array}$ & $\begin{array}{l}0.488 * \\
(1.96)\end{array}$ & $0.340^{*}$ & (1.88) \\
\hline
\end{tabular}

Panel A reports default risk and firm characteristics for DLI portfolios between January 2003 and December 2015. Details of variable constructions are provided in the Appendix (Table 12). Portfolios 1 and 5 represent sample quintiles that comprise stocks with the lowest and highest default risk, respectively. $\mathrm{H}-\mathrm{L}$ represents a portfolio that is long portfolio 5 and short portfolio 1. Panel B reports the monthly equalweighted (EW) and value-weighted (VW) raw returns. Panel $\mathrm{C}$ reports the monthly equal-weighted and value-weighted alphas from the CAPM model. The corresponding $t$-statistics in parentheses are adjusted using heteroscedasticity-consistent standard errors of Newey and West (1987)

Statistical significance at the 10,5 , and $1 \%$ levels is denoted by $*, * *$, and $* * *$, respectively

time-series averages of cross-sectional medians. Overall, Panel A suggests that firms tend to have lower default risks if they are larger in size, more profitable, less leveraged and having relatively lower state-ownership. To verify that our default likelihood measure is capable of capturing variations in default risk, we also apply two alternative default risk measures, DTD_CRI (Duan et al. 2012) ${ }^{11}$ and Z-score (Altman 1968). It is found that both measures decrease monotonically from portfolio 1 to portfolio 5 , hence confirming that portfolio 5 has the highest default risk and vice versa.

For portfolio returns, we first compute the arithmetic average monthly expected stock return for each portfolio, and then compute the average return across the sample period.

\footnotetext{
11 We are grateful to the Credit Research Initiative at the Risk Management Institute of National University of Singapore for providing us the data. DTD_CRI is calculated using a modified Merton-type model of Duan et al. (2012).
} 
Table 6 Returns on dependent double sorted DLI-Size (B/M) portfolios

\begin{tabular}{|c|c|c|c|c|c|c|}
\hline & \multicolumn{5}{|c|}{ DLI Quintiles } & \multirow[b]{2}{*}{$\mathrm{H}-\mathrm{L}$} \\
\hline & Low (1) & 2 & 3 & 4 & High (5) & \\
\hline \multicolumn{7}{|c|}{ Panel A DLI and size } \\
\hline \multicolumn{7}{|l|}{ Size } \\
\hline Small & $\begin{array}{l}2.451 * * * \\
(2.81)\end{array}$ & $\begin{array}{l}2.653 * * * \\
(2.96)\end{array}$ & $\begin{array}{l}3.072 * * * \\
(3.44)\end{array}$ & $\begin{array}{l}2.871 * * * \\
(3.13)\end{array}$ & $\begin{array}{l}3.313 * * * \\
(3.48)\end{array}$ & $\begin{array}{l}0.862 * * * \\
(3.31)\end{array}$ \\
\hline Large & $\begin{array}{l}1.555^{* * *} \\
(2.19)\end{array}$ & $\begin{array}{l}1.598 * * \\
(2.07)\end{array}$ & $\begin{array}{l}1.571 * * \\
(1.98)\end{array}$ & $\begin{array}{l}1.644 * * \\
(2.04)\end{array}$ & $\begin{array}{l}1.740 * * \\
(2.13)\end{array}$ & $\begin{array}{l}0.185 \\
(0.40)\end{array}$ \\
\hline Small-large & $\begin{array}{l}0.896^{*} \\
(1.95)\end{array}$ & $\begin{array}{l}1.055^{* *} \\
(2.41)\end{array}$ & $\begin{array}{l}1.501 * * * \\
(3.65)\end{array}$ & $\begin{array}{l}1.311^{* * * *} \\
(3.22)\end{array}$ & $\begin{array}{l}1.573^{* * * *} \\
(3.44)\end{array}$ & \\
\hline \multicolumn{7}{|c|}{ Panel B DLI and BM } \\
\hline \multicolumn{7}{|l|}{$\mathrm{B} / \mathrm{M}$} \\
\hline Growth & $\begin{array}{l}1.584 * * \\
(2.06)\end{array}$ & $\begin{array}{l}1.778^{* *} \\
(2.15)\end{array}$ & $\begin{array}{l}1.803 * * \\
(2.13)\end{array}$ & $\begin{array}{l}2.161^{* *} \\
(2.38)\end{array}$ & $\begin{array}{l}2.297 * * \\
(2.51)\end{array}$ & $\begin{array}{l}0.713 * * * \\
(2.60)\end{array}$ \\
\hline Value & $\begin{array}{l}1.881 * * \\
(2.25)\end{array}$ & $\begin{array}{l}2.137 * * \\
(2.51)\end{array}$ & $\begin{array}{l}2.257 * * \\
(2.59)\end{array}$ & $\begin{array}{l}2.241 * * \\
(2.54)\end{array}$ & $\begin{array}{l}2.454 * * * \\
(2.82)\end{array}$ & $\begin{array}{l}0.574 * * \\
(1.99)\end{array}$ \\
\hline Value-growth & $\begin{array}{l}0.296 \\
(0.90)\end{array}$ & $\begin{array}{l}0.359 \\
(1.21)\end{array}$ & $\begin{array}{l}0.454 \\
(1.52)\end{array}$ & $\begin{array}{l}0.080 \\
(0.26)\end{array}$ & $\begin{array}{l}0.158 \\
(0.52)\end{array}$ & \\
\hline
\end{tabular}

This table reports the monthly equal-weighted (EW) average returns by using two-way dependent sorts between 2003 and 2015. At the end of each month, firms are sorted into three portfolios based on their past month's market capitalization (SIZE) and book-to-market ratio (B/M). Within each SIZE or B/M portfolio, firms are dependently sorted into five portfolios based on their past month's default likelihood indicator (DLI). The portfolios are rebalanced monthly. The corresponding t-statistics are adjusted using the heteroscedasticity-consistent standard errors of Newey and West (1987)

$*$, **, and *** denote statistical significant level at 10,5 and $1 \%$, respectively. The results for medium size and medium B/M portfolios are not tabulated to conserve space but available from the authors on request

Panels B and C (Table 5) show a clear positive relationship between DLI and expected stock returns and such a finding is robust to both equal-weight (EW) and value-weighted (VW) methods, and to the raw returns and risk-adjusted returns. ${ }^{12}$ Based on the EW estimation, the monthly expected raw returns for portfolio 5 and portfolio 1 are $2.402 \%$ and $1.826 \%$ respectively and the return spread for all five portfolios are statistically significant at a $1 \%$ level $(0.590 \%$ with $\mathrm{t}=2.60)$. Panel $\mathrm{C}$ shows consistent results to Panel $\mathrm{B}$ where portfolio with higher default risk would generate higher stock returns.

Fama and French (1992, 1993) and Vassalou and Xing (2004) show that default risk premium is associated with the size and value effect. Therefore, we test whether size and $\mathrm{B} / \mathrm{M}$ are proxying default risk in Chinese stock market using dependent double-sorting approach. We firstly sort sample firms into three portfolios based on their past month's market capitalization (SIZE), and book-to-market ratio (B/M). For each SIZE (small, medium and large) and B/M (growth, medium and value) portfolio, we further sort stocks

\footnotetext{
12 Due to the lack of consistency in the explanatory power of the Fama-French three factors in pricing Chinese stock returns documented in prior studies (Lin et al. 2012; Morelli 2012; Hu et al. 2018), we didn't report the alphas from the three-factor model. Results are available from the authors on request.
} 
Table 7 Returns on dependent double sorted DLI-ownership portfolios

\begin{tabular}{|c|c|c|c|c|c|c|}
\hline & \multicolumn{5}{|c|}{ DLI quintiles } & \multirow[b]{2}{*}{$\mathrm{H}-\mathrm{L}$} \\
\hline & Low (1) & 2 & 3 & 4 & High (5) & \\
\hline \multicolumn{7}{|l|}{ Panel A DLI and SO } \\
\hline \multicolumn{7}{|l|}{$\mathrm{SO}(\%)$} \\
\hline Zero SO & $\begin{array}{l}1.826^{* *} \\
(2.36)\end{array}$ & $\begin{array}{l}2.030 * * \\
(2.49)\end{array}$ & $\begin{array}{l}2.210 * * * \\
(2.64)\end{array}$ & $\begin{array}{l}2.313^{* * * *} \\
(2.73)\end{array}$ & $\begin{array}{l}2.592 * * * \\
(2.92)\end{array}$ & $\begin{array}{l}0.766^{* * *} \\
(2.10)\end{array}$ \\
\hline High $(\mathrm{SO}>50 \%)$ & $\begin{array}{l}1.730 * * \\
(2.02)\end{array}$ & $\begin{array}{l}2.096 * * \\
(2.61)\end{array}$ & $\begin{array}{l}1.970 * * \\
(2.08)\end{array}$ & $\begin{array}{l}1.960 * * \\
(2.35)\end{array}$ & $\begin{array}{l}2.080 * * \\
(2.30)\end{array}$ & $\begin{array}{l}0.350 \\
(0.93)\end{array}$ \\
\hline Zero-high & $\begin{array}{l}0.096 \\
(0.53)\end{array}$ & $\begin{array}{l}-0.067 \\
(-0.21)\end{array}$ & $\begin{array}{l}0.240 \\
(0.72)\end{array}$ & $\begin{array}{l}0.453 \\
(1.42)\end{array}$ & $\begin{array}{l}0.512 \\
(1.41)\end{array}$ & \\
\hline \multicolumn{7}{|c|}{ Panel B DLI and SOE } \\
\hline Non SOEs & $\begin{array}{l}2.066^{* *} \\
(2.54)\end{array}$ & $\begin{array}{l}2.193^{* * * *} \\
(2.57)\end{array}$ & $\begin{array}{l}2.182 * * \\
(2.56)\end{array}$ & $\begin{array}{l}2.475 * * * \\
(2.84)\end{array}$ & $\begin{array}{l}2.859 * * * \\
(3.11)\end{array}$ & $\begin{array}{l}0.793 * * * \\
(2.67)\end{array}$ \\
\hline SOEs & $\begin{array}{l}1.779 * * \\
(2.21)\end{array}$ & $\begin{array}{l}1.792 * * \\
(2.23)\end{array}$ & $\begin{array}{l}1.983 * * \\
(2.39)\end{array}$ & $\begin{array}{l}2.130 * * \\
(2.53)\end{array}$ & $\begin{array}{l}2.205^{* * * *} \\
(2.75)\end{array}$ & $\begin{array}{l}0.426 \\
(1.54)\end{array}$ \\
\hline Non SOEs-SOEs & $\begin{array}{l}0.287 \\
(1.50)\end{array}$ & $\begin{array}{l}0.401 * \\
(1.67)\end{array}$ & $\begin{array}{l}0.308 \\
(1.27)\end{array}$ & $\begin{array}{l}0.470 * * \\
(2.23)\end{array}$ & $\begin{array}{l}0.654 * * \\
(2.11)\end{array}$ & \\
\hline
\end{tabular}

This table reports the monthly equal-weighted (EW) average returns by using two-way dependent sorts between 2003 and 2015. At the end of each month, firms are sorted into three (two) portfolios based on their state-ownership percentage (SO), and ownership structure (SOE). Within each SIZE, SO and SOE portfolio, firms are dependently sorted into five portfolios based on their past month's default likelihood indicator (DLI). The portfolios are rebalanced monthly. The corresponding t-statistics are adjusted using the heteroscedasticity-consistent standard errors of Newey and West (1987)

$*$, **, and *** denote statistical significant level at 10,5 and $1 \%$, respectively. The results for low SO $(0<\mathrm{SO} \leq 50 \%)$ portfolios are not tabulated to conserve space but available from the authors on request

into five subgroups based on their DLIs. Table 6 reports the average monthly stock returns for each subgroup. Specifically, Panels A and B reports the default risk effect controlling for firm size and B/M, respectively. Panel A of Table 5 shows that overall, high default risk stocks earn higher returns than low risk stocks; while, the risk premium is statistically insignificant for large firms where the return spread is $0.185 \%(t=0.40)$. This is consistent with existing literature (e.g. Hu et al. 2018) that firm size is the strongest factor in explaining the cross-section stock returns in Chinese stock markets and shareholders of large firms have a stronger bargaining power in debt refinancing and renegotiation (Garlappi et al. 2008). As a result, shareholders of large firms may not require an equivalent risk premium for additional risk bearing as those of small firms.

Panel B (Table 6) indicates that default risk is rewarded with higher returns in both growth firms $(0.713 \%, t=2.60)$ and value firms $(0.574 \%, t=1.99)$, Our findings are inconsistent with that of Vassalou and Xing (2004), where default risk premium is more pronounced among value firms. This could be due to the weak return predictive power of the B/M in China (Hilliard and Zhang 2015, Hu et al. 2018). In addition, our results suggest that the default risk effect is independent of $\mathrm{B} / \mathrm{M}$.

Based on the positive association between DLI and state-ownership observed in previous sections, we then apply dependent double-sorting to further explore the interaction 
between firms' default risk and ownership structure in determining expected stock returns. Hence, we firstly sort sample firms into either three or two portfolios based on their stateownership percentage (SO) and ownership structure (SOE). For each SO (zero, low and high state-ownership) and SOE (SOEs and non-SOEs) portfolio, we further sort stocks into five subgroups based on their DLIs. We then examine the average holding returns of each subgroup in the month following portfolio formation. Table 7 reports the average monthly stock returns for each subgroup. Panel A shows that the return spread between high and low default risk firms is $0.766 \%(t=2.10)$ per month for the zero SO sample, but smaller and not statistically significant for the high SO sample $(0.350 \%, t=0.93)$. In addition, the zero SO (non-SOE) and high default risk portfolios earn anomalously high returns $(2.592 \%$, $t=2.92 ; 2.859 \%, t=3.11$ ), indicating that default risk is rewarded with higher returns in zero SO and non-SOE firms as investors generally expect higher returns for holding stocks of those firms. Thus, our evidence supports the argument that shareholders of state-owned firms tend to have lower required rate of returns for default risk exposure as they tend to have 'shareholder advantage' (Garlappi et al. 2008) or they are more likely to be politically connected (Boubakri et al. 2012).

In addition, we examine the interaction between size and state-ownership in explaining the default risk-return relationship by performing triple sorts (Table 13, Appendix). Our results show that the default risk premium can be attributed more to state-ownership than firm size. As a robustness check, we apply CAPM to calculate risk-adjust returns of the double and trip sorted portfolios (Tables 14 and 15, Appendix).

\subsection{Cross-sectional analysis}

To provide a structural and multivariate view of the cross-sectional relationship between corporate default risk and expected stock returns, we further apply Fama and Macbeth (1973) cross-sectional regressions as specified below:

$$
\begin{gathered}
r_{i, t+1}-r_{f, t+1}=\alpha_{0}+\beta_{1} \ln (D L I)_{i, t}+\varepsilon_{i, t} \\
r_{i, t+1}-r_{f, t+1}=\alpha_{0}+\beta_{2} \ln (M V)_{i, t}+\beta_{3} \ln (B M)_{i, t}+\beta_{4} M O M_{i, t}+\varepsilon_{i, t} \\
r_{i, t+1}-r_{f, t+1}=\alpha_{0}+\beta_{1} \ln (D L I)_{i, t}+\beta_{2} \ln (M V)_{i, t}+\beta_{3} \ln (B M)_{i, t}+\beta_{4} M O M_{i, t}+\varepsilon_{i, t}
\end{gathered}
$$

where $r_{i, t+1}$ is the monthly raw return of stock $i$ in month $t+1 . r_{f, t+1}$ is the monthly-based 1-year Treasury-bill rate, $\ln (\mathrm{DLI})_{i, t}$ is the natural logarithm of the default likelihood indicator of stock $i, \ln (\mathrm{MV})_{i, t}$ is the natural logarithm of market capitalization of equity, $\ln (\mathrm{BM})_{i, t}$ is the natural logarithm of the ratio of the book value of equity for the previous fiscal year divided by market equity in month $t$, and $\mathrm{MOM}_{i, t}$ is the cumulative compounded stock returns of the previous 6 months at the end of month $t$.

In Eq. 5, we only include default risk (DLI) as the independent variable to explain cross-sectional stock returns. Equation 6 represents the basic benchmark model and Eq. 7 includes both default risk and other three control variables as the independent variables. For each month $t$, we run Fama and Macbeth (1973) cross-sectional regressions of monthly excess returns on given variables. Table 8 presents the estimated coefficients on DLI and control variables, which are calculated as the time-series averages of monthly cross-sectional regression coefficients. The coefficients represent the premium returned to stockholders' risk exposure to each variable.

Specifically, our Fama-MacBeth regression considers the effect of DLIs (Models 1, 4 and 7) and firm fundaments (Models 2, 5 and 8) independently and their combined effects 


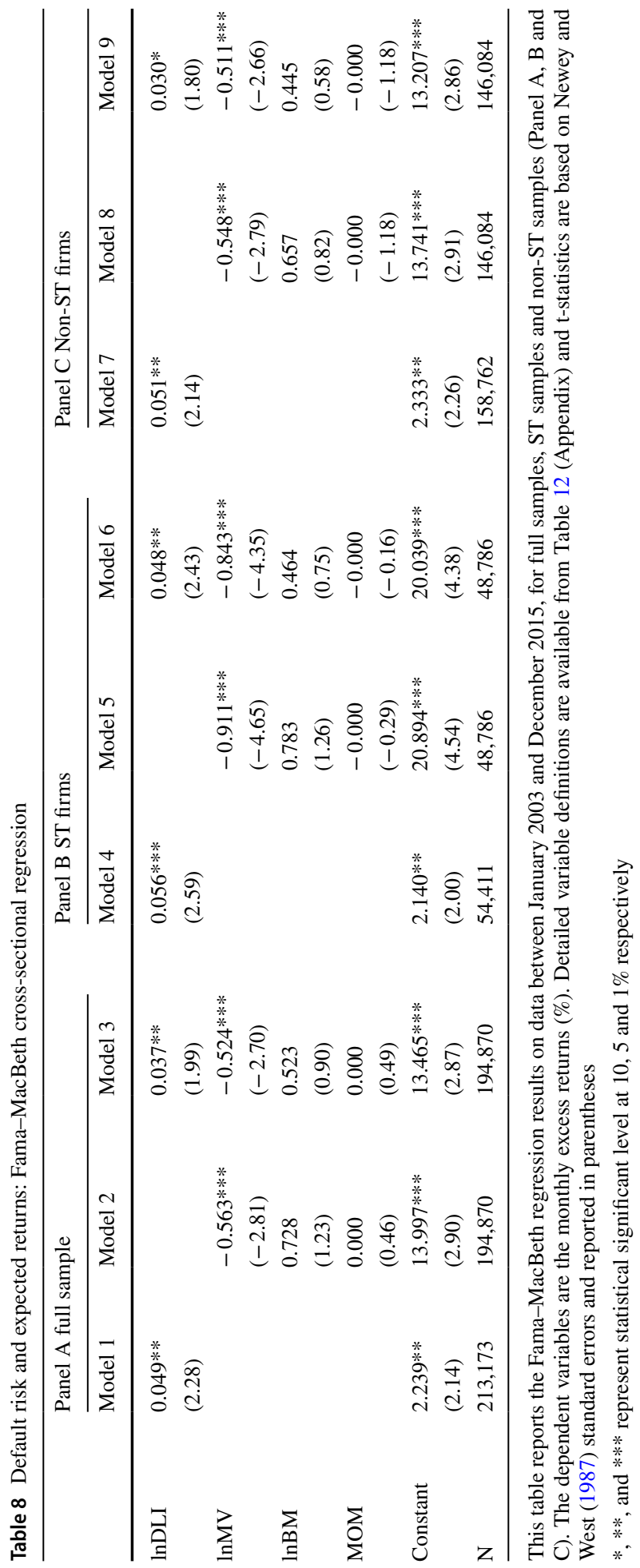


(Models 3, 6 and 9) on monthly excess returns. Table 8 shows consistent evidence on the positive relationship between corporate default risk and stock returns over different sample groups, i.e. full, ST and non-ST samples. For example, holding firm fundamentals constant, one unit increase in corporate default risk, $\ln (\mathrm{DLI})$, would reward investors with an excess monthly return of about $0.04 \%$ for full samples (Model 3), $0.05 \%$ for ST samples (Model 6) and $0.03 \%$ for non-ST samples (Model 9). Additionally, we show that the book-to-market ratio is positively but insignificantly related to the cross-section of returns. This is consistent with our earlier findings in double sorting. Overall, Table 8 shows clear evidence on the existence of cross-sectional return predictability of default risk in Chinese stock markets.

To further investigate the impact of corporate ownership structure on the cross-sectional pricing of default risk, we divide the full sample, according to the percentage of stateownership and their ownership status, into SOE or non-SOE, and re-run the cross-sectional models (Table 9). As expected, firms with zero state-ownership, or characterized as nonSOEs, tend to reward the investors with higher risk premium but for both high SO and SOE firms, the coefficients of DLI are statistically insignificant. Such a finding is consistent with our prior estimation based on the double sorting approach (Table 7). Findings revealed in Table 9 reinforce the nature of inefficiency of Chinese capital market where shareholders of SOEs are not fully rewarded for bearing higher default risk and the state-ownership is still perceived by investors as offering implicit guarantee for financial distress. For example, for firms with zero SO or non-SOEs, investors will be rewarded with approximately $0.04 \%$ monthly excess return for bearing an extra unit of default risk after controlling for firm characteristics. Overall, the results suggest that default risk is not consistently priced in cross-sectional stock returns among SOEs.

To examine the marginal effect of state ownership on the default risk-return relationship, we focus on the interaction between state ownership and default risk using crosssectional regression analysis. Table 10 reports the result of the Fama and MacBeth (1973) regression. In Model 1 and Model 2, we run simple regressions by adding firms' state ownership (SO) and ownership characteristics (SOE) to Eq. (7). The coefficients of both SO and SOE are negative but insignificant, suggesting that state ownership is not significantly associated with cross-sectional stock returns.

In Model 3 and Model 4, we include the extra interaction term, $\ln (\mathrm{DLI}) * \mathrm{SO}$ and $\ln (\mathrm{DLI}) * \mathrm{SOE}$. As predicted, we show that the coefficients of the interaction terms between default risk and state ownership are -0.452 (t-statistics $=-2.06$ ) and -0.304 (t-statistics $=-2.34$ ) and both are statistically significant. This result suggests that for firms with high default risk, state ownership has a negative impact on stock returns. In Model 5 and Model 6, we include an additional interaction term, $\ln (\mathrm{DLI}) * \ln (\mathrm{MV}) * \mathrm{SO}$ and $\ln (\mathrm{DLI}) * \ln (\mathrm{MV}) * \mathrm{SOE}$ respectively. The coefficients on the three-way interaction terms are significantly positive, indicating that the interaction between default risk and state ownership is more pronounced among small firms. In addition, the coefficients on the interaction between default risk and state ownership remains significant and have similar magnitude as those in Model 3 and Model 4. Thus, our main conclusion remains unaltered.

\subsection{Robustness tests}

To check the robustness of our results, we perform additional tests along two dimensions. First, we assess whether the cross-sectional results sorted by state-ownership are robust with alternative measure of firm-level default risk. We replace DLI with the distance-todefault (DTD_CRI) proposed by Duan et al. (2012). Firm-level DTD_CRI is estimated 


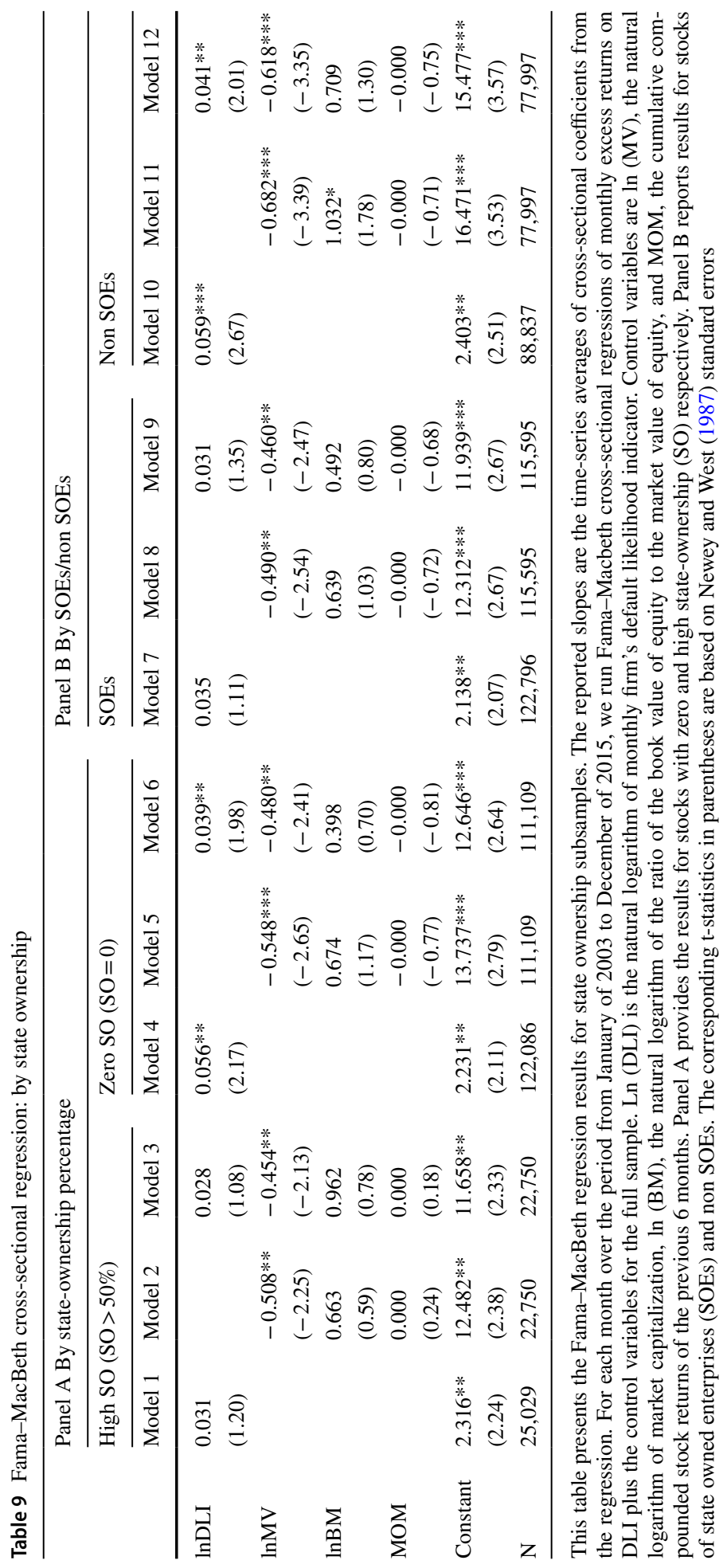


Table 10 Fama-MacBeth cross-sectional regression with interaction terms

\begin{tabular}{|c|c|c|c|c|c|c|}
\hline & Model 1 & Model 2 & Model 3 & Model 4 & Model 5 & Model 6 \\
\hline $\operatorname{lnDLI}$ & $\begin{array}{l}0.032 * \\
(1.90)\end{array}$ & $\begin{array}{l}0.033 * * \\
(2.01)\end{array}$ & $\begin{array}{l}0.037 \\
(1.59)\end{array}$ & $\begin{array}{l}0.031 \\
(1.38)\end{array}$ & $\begin{array}{l}0.030 \\
(1.51)\end{array}$ & $\begin{array}{l}0.029 \\
(1.33)\end{array}$ \\
\hline $\operatorname{lnMV}$ & $\begin{array}{l}-0.530 * * * \\
(-2.98)\end{array}$ & $\begin{array}{l}-0.512 * * * \\
(-2.92)\end{array}$ & $\begin{array}{l}-0.529 * * * \\
(-2.97)\end{array}$ & $\begin{array}{l}-0.510 * * * \\
(-2.91)\end{array}$ & $\begin{array}{l}-0.574 * * * \\
(-3.11)\end{array}$ & $\begin{array}{l}-0.631 \text { *** } \\
(-3.38)\end{array}$ \\
\hline $\ln B M$ & $\begin{array}{l}0.538 \\
(0.93)\end{array}$ & $\begin{array}{l}0.645 \\
(1.16)\end{array}$ & $\begin{array}{l}0.535 \\
(0.92)\end{array}$ & $\begin{array}{l}0.645 \\
(1.17)\end{array}$ & $\begin{array}{l}0.554 \\
(0.96)\end{array}$ & $\begin{array}{l}0.656 \\
(1.19)\end{array}$ \\
\hline MOM & $\begin{array}{l}0.000 \\
(0.49)\end{array}$ & $\begin{array}{l}0.000 \\
(0.58)\end{array}$ & $\begin{array}{l}0.000 \\
(0.51)\end{array}$ & $\begin{array}{l}0.000 \\
(0.61)\end{array}$ & $\begin{array}{l}0.000 \\
(0.50)\end{array}$ & $\begin{array}{l}0.000 \\
(0.59)\end{array}$ \\
\hline $\mathrm{SO}$ & $\begin{array}{l}-0.416 \\
(-1.37)\end{array}$ & & $\begin{array}{l}-0.460 \\
(-1.40)\end{array}$ & & $\begin{array}{l}-0.330 \\
(-1.01)\end{array}$ & \\
\hline SOE & & $\begin{array}{l}-0.087 \\
(-0.66)\end{array}$ & & $\begin{array}{l}-0.091 \\
(-0.52)\end{array}$ & & $\begin{array}{l}0.014 \\
(0.08)\end{array}$ \\
\hline $\operatorname{lnDLI} * \mathrm{SO}$ & & & $\begin{array}{l}-0.452 * * \\
(-2.06)\end{array}$ & & $\begin{array}{l}-0.429 * \\
(-1.93)\end{array}$ & \\
\hline $\operatorname{lnDLI} * \mathrm{SOE}$ & & & & $\begin{array}{l}-0.304 * * \\
(-2.34)\end{array}$ & & $\begin{array}{l}-0.289^{*} \\
(-1.76)\end{array}$ \\
\hline $\operatorname{lnDLI}{ }^{*} \mathrm{MV}^{*} \mathrm{SO}$ & & & & & $\begin{array}{l}0.019 * \\
(1.82)\end{array}$ & \\
\hline $\operatorname{lnDLI} * \mathrm{MV}^{*} \mathrm{SOE}$ & & & & & & $\begin{array}{l}0.013 * * \\
(1.98)\end{array}$ \\
\hline Constant & $\begin{array}{l}13.549 * * * \\
(3.15)\end{array}$ & $\begin{array}{l}13.157 * * * \\
(3.12)\end{array}$ & $\begin{array}{l}13.575^{* * * *} \\
(3.16)\end{array}$ & $\begin{array}{l}13.128 * * * \\
(3.11)\end{array}$ & $\begin{array}{l}14.494 * * * \\
(3.29)\end{array}$ & $\begin{array}{l}15.683 * * * \\
(3.55)\end{array}$ \\
\hline $\mathrm{N}$ & 194,768 & 193,512 & 194,768 & 193,512 & 194,768 & 193,512 \\
\hline
\end{tabular}

This table presents the Fama-MacBeth regression results. The reported slopes are the time-series averages of cross-sectional coefficients from the regression. For each month over the period from January of 2003 to December of 2015, we run Fama-Macbeth cross-sectional regressions of monthly excess returns on DLI plus the control variables for the full sample. $\operatorname{Ln}(\mathrm{DLI})$ is the natural logarithm of monthly firm's default likelihood indicator. Control variables are $\ln (\mathrm{MV})$, the natural logarithm of market capitalization; $\ln (\mathrm{BM})$, the natural logarithm of the ratio of the book value of equity to the market value of equity; MOM, the cumulative compounded stock returns of the previous 6 months; SO, ratio of state-ownership shares; SOE, a dummy equals to 1 if the firm's ultimate controlling party is the state. Interaction terms $\ln (\mathrm{DLI}) * \mathrm{SO}$, $\ln (\mathrm{DLI}) * \mathrm{SOE}, \ln (\mathrm{DLI}) * \ln (\mathrm{MV}) * \mathrm{SO}$ and $\ln (\mathrm{DLI}) * \ln (\mathrm{MV}) * \mathrm{SOE}$ are computed as the product of corresponding variables. The corresponding t-statistics in parentheses are based on Newey and West (1987) standard errors

based on the structure model using the transformed-dada maximum likelihood estimation method, accounting for the high leverage feature of some financial firms. The dramatic economic development of China has been accompanied by an increase in firms' (especially SOEs) leverage ratio. We, therefore, aim to test whether the relationship between stock returns and default probability is sensitive to the estimation of default risk. Table 11 shows consistent results to our earlier findings (Tables 8 and 9) that the loading on $\ln$ (DTD_CRI) is negative for the full sample, suggesting that firms with higher distance-to-default tend to have lower expected stock returns. In particular, the loadings on $\ln ($ DTD_CRI) are negative and statistically significant for low SO and non-SOEs firms, but are insignificant for both high SO and SOEs firms. This is also consistent with the findings in tripe sorting 
Table 11 Cross-sectional regression: DLI_CRI as a measure of default risk

\begin{tabular}{llllllll}
\hline & $\begin{array}{l}\text { Full sample } \\
\text { Model 1 }\end{array}$ & $\begin{array}{l}\text { STs } \\
\text { Model 2 }\end{array}$ & $\begin{array}{l}\text { Non-STs } \\
\text { Model 3 }\end{array}$ & $\begin{array}{l}\text { Zero SO } \\
\text { Model 4 }\end{array}$ & $\begin{array}{l}\text { High SO } \\
\text { Model 5 }\end{array}$ & $\begin{array}{l}\text { Non-SOEs } \\
\text { Model 7 }\end{array}$ & $\begin{array}{l}\text { SOEs } \\
\text { Model } 8\end{array}$ \\
\hline lnDTD_CRI & $-0.305^{*}$ & $-0.419 * *$ & $-0.340^{*}$ & $-0.506^{* *}$ & -0.171 & $-0.400^{*}$ & -0.273 \\
& $(-1.71)$ & $(-2.42)$ & $(-1.70)$ & $(-2.26)$ & $(-0.98)$ & $(-1.90)$ & $(-1.53)$ \\
lnMV & $-0.573^{* * *}$ & $-0.858^{* * *}$ & $-0.546^{* * *}$ & $-0.547 * * *$ & $-0.581^{* * *}$ & $-0.687 * * *$ & $-0.503 * * *$ \\
& $(-3.05)$ & $(-4.43)$ & $(-2.94)$ & $(-2.86)$ & $(-3.06)$ & $(-3.55)$ & $(-2.68)$ \\
lnBM & 0.592 & 0.776 & 0.198 & 0.338 & 0.878 & 0.713 & 0.651 \\
& $(0.96)$ & $(1.20)$ & $(0.25)$ & $(0.53)$ & $(1.25)$ & $(1.16)$ & $(0.95)$ \\
MOM & 0.000 & 0.000 & -0.000 & -0.000 & -0.000 & -0.000 & -0.000 \\
& $(0.32)$ & $(0.55)$ & $(-1.37)$ & $(-0.18)$ & $(-0.96)$ & $(-0.09)$ & $(-1.01)$ \\
Constant & $14.612 * * *$ & $20.419 * * *$ & $14.249 * * *$ & $14.461 * * *$ & $14.339 * * *$ & $17.114 * * *$ & $12.888 * * *$ \\
& $(3.26)$ & $(4.55)$ & $(3.22)$ & $(3.18)$ & $(3.19)$ & $(3.75)$ & $(2.88)$ \\
N & 162,508 & 43,829 & 118,679 & 95,650 & 18,099 & 69,264 & 93,244 \\
\hline
\end{tabular}

This table presents the Fama-MacBeth regression results for different samples, including the full sample, ST firms, non-ST firms, zero state-ownership firms, high state-ownership firms, non-SOES and SOEs. The reported slopes are the time-series averages of cross-sectional coefficients from the regression. For each month over the period from January of 2003 to December of 2015, we run Fama-Macbeth cross-sectional regressions of monthly percentage excess returns on DLI plus the control variables for the full sample. Ln (DLI_CRI) is the natural logarithm of monthly firm's distant to default from CRI. The control variables: ln (MV) is the natural logarithm of market capitalization; ln (BM) is the natural logarithm of the ratio of the book value of equity to the market value of equity; and MOM is the cumulative compounded stock returns of the previous 6 months. The corresponding t-statistics in parentheses are based on Newey and West (1987) standard errors

(Appendix Table 15), which shows that the positive default risk-return relationship is more pronounced in small and zero SO (or non-SOEs) firms.

Secondly, we check the robustness of our default risk measure. According to Merton's model, default can only occur on the day of maturity. Once the value of the firm falls below the default threshold, the firm will default. The implementation of the structural models needs to specify the level of the default point, which may affect the model accuracy significantly. Since the forecasting horizon is 1-year in our estimation, the principal of short-term debt should be considered as the default point (Leland 2004). According to Crosbie and Bohn (2003), the chosen default point by Moody's KMV model is generally in between the short-term debt and total debt. This is because firms' outstanding long-term debt position may affect their holding of short-term debt as the latter is rolling over continuously (Vassalou and Xing 2004).

Hence, we use an alternative default point - the principal of short-term debt plus $75 \%$ of long-term debt (Huang and He 2010) to test the robustness of our tested results. We plot the Receiver Operating Characteristic (ROC) curve for the two models with different default points. Figure 2 illustrates the trade-off between Type I error (properly labeling firms that are distressed or default) and Type II error (incorrectly identifying firms that will survive). The area under the ROC curve (AUC) shows the accuracy of different models. The diagonal line represents a random model with no predictability power $(A U C=0)$. A 


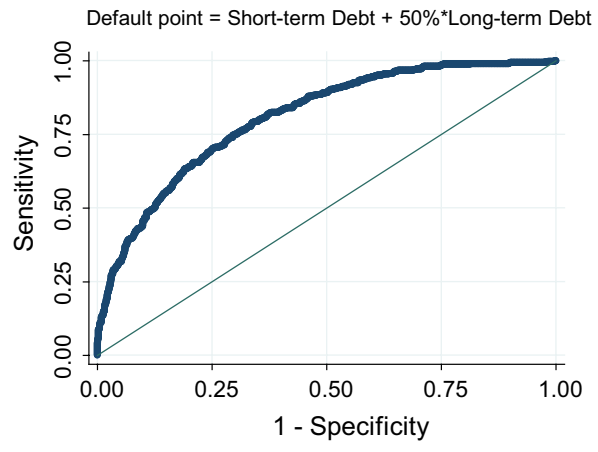

Area under ROC curve $=0.8059$

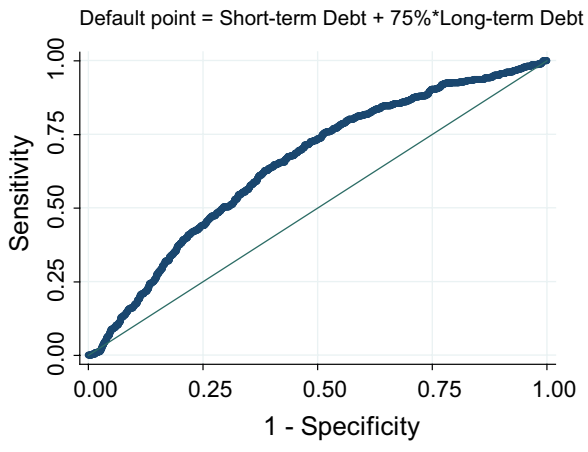

Area under ROC curve $=0.6482$

Fig. 2 ROC curves of models with alternative default barrier. This figure shows the ROC curves for the default risk models with default point of short-term debt plus 50\% long-term debt (left) and short-term debt plus $75 \%$ long-term debt (right). In each month, firms are ranked from highest default probability to lowest default probability based on the two models, and the percentage of ST and delisted firms in each percentile is calculated. The figures are then cumulated to generate the ROC for the two models. The $45^{\circ}$ line refers to the ROC curve under a model with no predictability

model is considered to be an improvement over the random model if the AUC is greater than 0.5 (Fawcett 2006). As shown in Fig. 2, both of the two lines are well above the diagonal line. Specifically, the AUC of the two models are 0.81 and 0.65 respectively, indicating that predicative power of the model with short-term debt plus 50 percent of long-term debt as the default barrier is much stronger, along with our earlier results being robust.

\subsection{Why the SOE default risk exposure is not returned correctly?}

Earlier results show consistent evidence that the positive relationship between default risk and stock return diminishes among SOEs which have higher default risk than their nonSOE counterparts. In this section, we discuss the possible reasons behind such an anomaly we observe from SOEs.

Recent empirical evidence (Filipe et al. 2016) has suggested that the anomaly could be driven by the idiosyncratic part of default risk where the systematic part is positively related to stock returns. This may apply to the setting of SOEs in China which are more likely to operate in certain industries, such as manufacturing and infrastructure. If this is to be the reason, we expect that the effects of state-ownership on default risk (DLIs) would be statistically insignificant because such effects have been captured by the industry fixed effects. Our empirical results (Appendix Table 17) reject this conjecture and show that SOEs still have higher default risks even controlling for industry effects.

The second possible reason could be that in credit markets, SOEs have a competitive advantage than non-SOEs and the real default risk effects are lower for SOEs than for nonSOEs. This possibility is especially prominent in Chinese markets where SOBs implement a 'soft-lending' practice to SOE borrowers who are in a stronger position than non-SOEs 

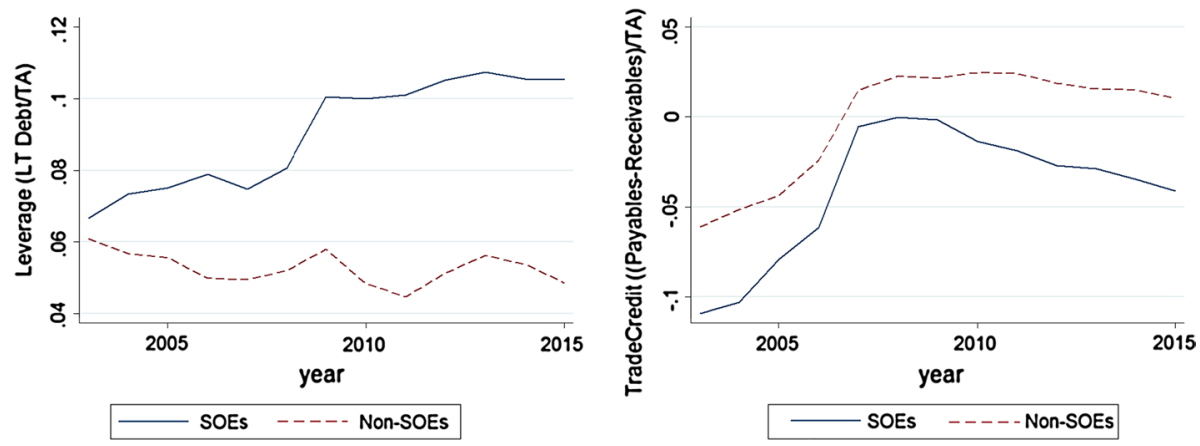

Fig. 3 A comparison between SOEs and non-SOEs on the reliance on long term finance and trade credit. a Leverage ratio of SOEs and non-SOEs, $\mathbf{b}$ trade credit of SOEs and non-SOEs. This figure reports the average leverage ratio (long-term debt to total assets) and trade credit [(Accounts payable-accounts receivable)/ total assets] of the sample firms by ownership type from 2013 to 2015 . SOEs refer to the listed firms whose ultimate control shareholders are government entities

in negotiating loan deals and renegotiating existing loan facilities (Sapienza 2004; Lu et al. 2012). Figure 3 shows documentary supporting evidence derived from our data. Panel A shows that SOEs have become more highly leveraged (long-term liability to total asset ratio) overtime compared with non-SOEs over our data period. Compared with SOEs, nonSOEs rely more heavily on trade credit (Panel B). As a result, Fig. 3 shows clear evidence that SOEs have a better access to formal credit in China and a certain amount of default risk could have a stronger adverse effect on the performance of non-SOEs than on SOEs. Similar empirical evidence on shareholder advantage in access bank finance is also available from Garlappi et al. (2008), Garlappi and Yan (2011) and etc.

Strongly related to the second reason, the third reason could be the association between political connections and cost of equity. The benefits that firms obtained from government support can reduce the cost of equity capital (Boubakri et al. 2012). Overall, our early results are supportive of a negative relationship between political connection (i.e. stateownership) and costs of equity (i.e. stock returns), especially for high default risk firms. Such a relationship is driven by the tax benefits, soft budgeting (Boubakri et al. 2012) and government bailout (Faccio et al. 2006).

\section{Conclusion}

Existing empirical evidence on the cross-sectional relationship between default risk and expected stock returns is inconclusive. On one hand, a positive relationship has been widely captured in developed markets (e.g. Vassalou and Xing 2004) and on the other, a 'distress puzzle' may happen in a bankruptcy process (Campbell et al. 2008) where stock returns are negatively related to corporate risk. What is little known is the nature of such 
a 'risk-return' relationship in Chinese stock markets with unique features. To advance knowledge in emerging financial market, this paper applies a structural model to measure firm-level default probabilities and provides a comprehensive investigation on the relationship between default risk and stock returns in China by explicitly considering the moderating effects of state-ownership.

We run a rich set of tests and show consistent evidence that first, state-ownership is positively associated with corporate default risk and firms with high state-ownership tend to have greater default risk. Second, we show that the positive 'risk-return' relationship does exist in Chinese stock markets but for those non-SOEs only. Overall, the 'high-minus-low' investment strategy based on default risk would generate an average abnormal monthly return of $0.475 \%$ (EW) and $0.340 \%$ (VW). However, our results do not support such a positive 'risk-return' relationship for SOEs, suggesting that shareholders of SOEs would not be compensated appropriately by bearing additional corporate default risk. Our results are robust to a variety of specifications.

Our results have three important implications. First, for Chinese government and creditors, it is important to acknowledge the high default risk associated with SOEs and such a factor needs to be taken into account in the loan granting process, especially when government guarantee for loans issued to some SOEs (for instance, some sectors are facing a serious threat of overcapacity) becomes weakened. Second, we show that shareholders of SOEs are not returned appropriately to compensate their exposure to default probabilities, which may not necessarily reflect the firm's exposure to systematic default risk. Thus, we call for future research to focus on the modifications of default risk estimation models for Chinese firms, and to separately test the contribution of systematic and idiosyncratic default risk to total default risk. Third, our research sheds light on the effect of firms' ownership structure on stock returns of high default risk firms. This evidence can be further tested by investigating the impact of government ownership on firm's cost of equity in China.

Acknowledgements We thank Prof. Cheng-Few-Lee, Editor-in-Chief, and an anonymous referee for their insightful comments which have significantly improved the paper. Dr. Dan Luo would also like to acknowledge the financial support provided by the National Natural Science Foundation of China (71672010).

Open Access This article is distributed under the terms of the Creative Commons Attribution 4.0 International License (http://creativecommons.org/licenses/by/4.0/), which permits unrestricted use, distribution, and reproduction in any medium, provided you give appropriate credit to the original author(s) and the source, provide a link to the Creative Commons license, and indicate if changes were made.

\section{Appendix 1}

See Tables 12, 13, 14, 15, 16 and 17 and Fig. 4. 
Table 12 Description of Variables

\begin{tabular}{|c|c|c|}
\hline Variables & Descriptions & Definitions \\
\hline $\mathrm{r}_{\mathrm{it}(\text { Return})}$ & Monthly stock returns & $\left(\right.$ Price $_{t}-$ Price $\left._{t-1}\right) /$ Price $_{t-1}$ \\
\hline $\mathrm{r}_{\mathrm{ft}}$ & Risk-free rate & Monthly series of 1-year Treasury-bill rate \\
\hline $\mathrm{V}_{\mathrm{AT}}$ & Value of total assets & $d V_{A t}=\mu V_{A t} d t+\sigma_{A} V_{A t} d W$ \\
\hline $\mathrm{D}$ & Value of debt & $\begin{array}{l}\text { Book value of debt (short-term debt plus half the long-term } \\
\text { debt) }\end{array}$ \\
\hline DLI & Default likelihood indicator & $\mathrm{P}\left(\mathrm{V}_{\mathrm{AT}}<\mathrm{D}\right)$ \\
\hline MV & Market capitalization of equity & Share price $*$ the number of shares outstanding \\
\hline $\mathrm{BM}$ & Book-to-market equity & Book value of equity/the market value of equity \\
\hline CAPX & Capital expenditure ratio & $\begin{array}{l}\text { Capital expenditure expenses scaled by book value of total } \\
\text { assets }\end{array}$ \\
\hline Leverage & Leverage ratio & Total liabilities/book value of total assets \\
\hline Profitability & Profitability ratio & Operating income/book value of equity \\
\hline $\mathrm{SO}$ & State-ownership & The ratio of shares owned by state to total shares outstanding \\
\hline SOE & State owned enterprise & Firms whose ultimate controlling party is the state \\
\hline MOM & Momentum returns & $\begin{array}{l}\text { The cumulative compounded stock returns of the previous } \\
6 \text { months }\end{array}$ \\
\hline DTD_CRI & Distant to default & How far away a firm is from default point \\
\hline Z-score & The Altman Z-score & $\mathrm{Z}-\mathrm{S}$ core $=\mathrm{A} * 3.3+\mathrm{B} * 0.99+\mathrm{C} * 0.6+\mathrm{D} * 1.2+\mathrm{E} * 1.4^{\mathrm{a}}$ \\
\hline
\end{tabular}

This table shows the names, descriptions and definitions of variables employed in this study. All of the data used to construct these variables are obtained from China Securities Market and Accounting Research (CSMAR)

${ }^{a}$ According to Altman (1968), A denotes EBIT/total assets; B denotes net sales/total assets; C denotes market value of equity/total liabilities; D denotes working capital/total assets; and E denotes retained earnings/ total assets 
Table 13 Triple sort portfolio returns: default effect controlled by size and ownership

\begin{tabular}{|c|c|c|c|c|c|c|}
\hline & \multicolumn{5}{|c|}{ DLI Quintiles } & \multirow[b]{2}{*}{$\mathrm{H}-\mathrm{L}$} \\
\hline & Low (1) & 2 & 3 & 4 & High (5) & \\
\hline \multicolumn{7}{|c|}{ Panel A Default risk effect controlled for Size and SO } \\
\hline \multicolumn{7}{|l|}{ Small } \\
\hline Zero SO & $\begin{array}{l}2.544 * * * \\
(2.78)\end{array}$ & $\begin{array}{l}2.676^{* * *} \\
(2.95)\end{array}$ & $\begin{array}{l}2.937 * * * \\
(3.19)\end{array}$ & $\begin{array}{l}3.078 * * * \\
(3.17)\end{array}$ & $\begin{array}{l}3.186^{* * * *} \\
(3.26)\end{array}$ & $\begin{array}{l}0.642 * * \\
(2.07)\end{array}$ \\
\hline High SO & $\begin{array}{l}2.543 * * * \\
(2.71)\end{array}$ & $\begin{array}{l}2.557 * * * \\
(2.88)\end{array}$ & $\begin{array}{l}2.890^{* * *} \\
(3.15)\end{array}$ & $\begin{array}{l}3.193 * * * \\
(3.31)\end{array}$ & $\begin{array}{l}3.078 * * * \\
(3.18)\end{array}$ & $\begin{array}{l}0.535^{*} \\
(1.75)\end{array}$ \\
\hline \multicolumn{7}{|l|}{ Large } \\
\hline Zero SO & $\begin{array}{c}1.213 \\
(1.65)\end{array}$ & $\begin{array}{l}1.371 * \\
(1.68)\end{array}$ & $\begin{array}{l}1.646^{* * *} \\
(2.01)\end{array}$ & $\begin{array}{l}1.616^{*} \\
(1.92)\end{array}$ & $\begin{array}{l}1.692 * * \\
(1.98)\end{array}$ & $\begin{array}{c}0.479 \\
(1.06)\end{array}$ \\
\hline High SO & $\begin{array}{l}1.541 * * \\
(2.04)\end{array}$ & $\begin{array}{l}1.454 * \\
(1.89)\end{array}$ & $\begin{array}{l}1.415^{*} \\
(1.80)\end{array}$ & $\begin{array}{l}1.501^{*} \\
(1.84)\end{array}$ & $\begin{array}{l}1.591 * \\
(1.91)\end{array}$ & $\begin{array}{c}0.050 \\
(0.11)\end{array}$ \\
\hline \multicolumn{7}{|c|}{ Panel B Default risk effect controlled for Size and $S O E$} \\
\hline \multicolumn{7}{|l|}{ Small } \\
\hline Non-SOEs & $\begin{array}{l}2.267 * * \\
(2.56)\end{array}$ & $\begin{array}{l}2.592 * * * \\
(2.88)\end{array}$ & $\begin{array}{l}2.757 * * * \\
(3.07)\end{array}$ & $\begin{array}{l}3.156^{* * * *} \\
(3.33)\end{array}$ & $\begin{array}{l}3.107 * * * \\
(3.25)\end{array}$ & $\begin{array}{l}0.840^{* * * *} \\
(2.72)\end{array}$ \\
\hline SOEs & $\begin{array}{l}2.611 * * * \\
(2.82)\end{array}$ & $\begin{array}{l}2.599 * * * \\
(2.82)\end{array}$ & $\begin{array}{l}2.998^{* * * *} \\
(3.18)\end{array}$ & $\begin{array}{l}3.146^{* * * *} \\
(3.19)\end{array}$ & $\begin{array}{l}3.099 * * * \\
(3.10)\end{array}$ & $\begin{array}{c}0.487 \\
(1.31)\end{array}$ \\
\hline \multicolumn{7}{|l|}{ Large } \\
\hline Non-SOEs & $\begin{array}{l}1.250 * \\
(1.69)\end{array}$ & $\begin{array}{l}1.609 * \\
(1.94)\end{array}$ & $\begin{array}{l}1.495^{*} \\
(1.76)\end{array}$ & $\begin{array}{l}1.660^{*} \\
(1.94)\end{array}$ & $\begin{array}{l}1.972 * * \\
(2.16)\end{array}$ & $\begin{array}{c}0.722 \\
(1.43)\end{array}$ \\
\hline SOEs & $\begin{array}{l}1.371 * \\
(1.85)\end{array}$ & $\begin{array}{l}1.480 * \\
(1.91)\end{array}$ & $\begin{array}{l}1.435^{*} \\
(1.79)\end{array}$ & $\begin{array}{l}1.542 * \\
(1.89)\end{array}$ & $\begin{array}{l}1.521 * \\
(1.86)\end{array}$ & $\begin{array}{l}0.150 \\
(0.37)\end{array}$ \\
\hline
\end{tabular}

This table represents monthly equal-weighted (EW) average portfolio returns by triple sorting on market capitalization (SIZE), state-ownership (SO/SOE) and default risk (DLI). The sample period is from January 2003 to December 2015. At the end of each month, firms are sorted independently based on their market capitalization (SIZE) and state-ownership (SO/SOE). And then for each SIZE/SO or SIZE/SOE portfolio, they are dependently sorted by default risk (DLI) into quintiles. The portfolios are rebalanced monthly. The corresponding t-statistics are adjusted using the heteroscedasticity-consistent standard errors of Newey and West (1987)

$*$, **, and *** denote statistical significant level at 10,5 and $1 \%$, respectively 
Table 14 Risk-adjusted returns dependent double sorted DLI-Size and DLI-Ownership portfolios

\begin{tabular}{|c|c|c|c|c|c|c|}
\hline & \multicolumn{5}{|c|}{ DLI Quintiles } & \multirow[b]{2}{*}{$\mathrm{H}-\mathrm{L}$} \\
\hline & Low (1) & 2 & 3 & 4 & High (5) & \\
\hline \multicolumn{7}{|c|}{ Panel A Size and DLI } \\
\hline \multicolumn{7}{|l|}{ Size } \\
\hline Small & $\begin{array}{l}1.223 * * \\
(2.11)\end{array}$ & $\begin{array}{l}1.368 * * \\
(2.40)\end{array}$ & $\begin{array}{l}1.550 * * * \\
(2.63)\end{array}$ & $\begin{array}{l}1.776 * * * \\
(2.82)\end{array}$ & $\begin{array}{l}1.862 * * * \\
(2.94)\end{array}$ & $\begin{array}{l}0.640 * * \\
(2.43)\end{array}$ \\
\hline Large & $\begin{array}{l}0.265 \\
(0.70)\end{array}$ & $\begin{array}{l}0.131 \\
(0.41)\end{array}$ & $\begin{array}{l}0.179 \\
(0.54)\end{array}$ & $\begin{array}{l}0.215 \\
(0.60)\end{array}$ & $\begin{array}{l}0.317 \\
(0.89)\end{array}$ & $\begin{array}{l}0.052 \\
(0.13)\end{array}$ \\
\hline Small-Large & $\begin{array}{l}0.958 * * \\
(1.98)\end{array}$ & $\begin{array}{l}1.237 * * * \\
(2.66)\end{array}$ & $\begin{array}{l}1.371 * * * \\
(2.71)\end{array}$ & $\begin{array}{l}1.561 * * * \\
(3.10)\end{array}$ & $\begin{array}{l}1.545^{* * * *} \\
(3.36)\end{array}$ & \\
\hline \multicolumn{7}{|l|}{ Panel B BM and SO } \\
\hline Zero SO & $\begin{array}{l}0.564 \\
(1.27)\end{array}$ & $\begin{array}{l}0.603 \\
(1.33)\end{array}$ & $\begin{array}{l}0.975 \\
(1.60)\end{array}$ & $\begin{array}{l}1.116^{*} \\
(1.82)\end{array}$ & $\begin{array}{l}1.245^{* *} \\
(2.04)\end{array}$ & $\begin{array}{l}0.681^{* * *} \\
(1.99)\end{array}$ \\
\hline High $(\mathrm{SO}>50 \%)$ & $\begin{array}{l}0.470 \\
(1.53)\end{array}$ & $\begin{array}{l}0.774 \\
(1.27)\end{array}$ & $\begin{array}{l}0.733^{*} \\
(1.97)\end{array}$ & $\begin{array}{l}0.723^{*} \\
(1.88)\end{array}$ & $\begin{array}{l}0.802 * * \\
(2.02)\end{array}$ & $\begin{array}{l}0.332 \\
(1.47)\end{array}$ \\
\hline Zero-High & $\begin{array}{l}0.094 \\
(0.37)\end{array}$ & $\begin{array}{l}-0.171 \\
(0.22)\end{array}$ & $\begin{array}{l}0.242 \\
(0.74)\end{array}$ & $\begin{array}{l}0.393 \\
(0.91)\end{array}$ & $\begin{array}{l}0.436 \\
(1.21)\end{array}$ & \\
\hline \multicolumn{7}{|c|}{ Panel C DLI and SOE } \\
\hline Non SOEs & $\begin{array}{l}0.680 \\
(1.43)\end{array}$ & $\begin{array}{l}0.765 \\
(1.54)\end{array}$ & $\begin{array}{l}0.904 * \\
(1.74)\end{array}$ & $\begin{array}{l}1.148 * * \\
(2.10)\end{array}$ & $\begin{array}{l}1.344 * * \\
(2.00)\end{array}$ & $\begin{array}{l}0.664 * * \\
(2.25)\end{array}$ \\
\hline SOEs & $\begin{array}{l}0.480 \\
(1.04)\end{array}$ & $\begin{array}{l}0.456 \\
(1.14)\end{array}$ & $\begin{array}{l}0.641 \\
(1.47)\end{array}$ & $\begin{array}{l}0.727 \\
(1.55)\end{array}$ & $\begin{array}{l}0.909 * * \\
(2.11)\end{array}$ & $\begin{array}{l}0.389 \\
(1.50)\end{array}$ \\
\hline Non SOEs-SOEs & $\begin{array}{l}0.200 \\
(1.09)\end{array}$ & $\begin{array}{l}0.309 \\
(1.42)\end{array}$ & $\begin{array}{l}0.263 \\
(1.37)\end{array}$ & $\begin{array}{l}0.421^{*} \\
(1.92)\end{array}$ & $\begin{array}{l}0.475^{* *} \\
(2.31)\end{array}$ & \\
\hline
\end{tabular}

This table reports the monthly equal-weighted (EW) average alphas by using two-way dependent sorts between 2003 and 2015. At the end of each month, firms are sorted into three (two) portfolios based on their past month's market capitalization (SIZE), state-ownership percentage (SO), and ownership structure (SOE). Within each SIZE, SO and SOE portfolio, firms are dependently sorted into five portfolios based on their past month's default likelihood indicator (DLI). The portfolios are rebalanced monthly. Portfolio risk-adjusted returns are alphas from the CAPM model. The corresponding t-statistics are adjusted using the heteroscedasticity-consistent standard errors of Newey and West (1987)

$*$, **, and $* * *$ denote statistical significant level at 10,5 and $1 \%$, respectively. The results for medium size portfolios and low SO portfolios are not tabulated to conserve space but available from the authors on request 
Table 15 Triple sort portfolio risk-adjusted returns: default effect controlled by size and ownership

\begin{tabular}{|c|c|c|c|c|c|c|}
\hline & \multicolumn{5}{|c|}{ DLI Quintiles } & \multirow[b]{2}{*}{$\mathrm{H}-\mathrm{L}$} \\
\hline & Low (1) & 2 & 3 & 4 & High (5) & \\
\hline \multicolumn{7}{|c|}{ Panel A Default risk effect controlled for size and SO } \\
\hline \multicolumn{7}{|l|}{ Small } \\
\hline Low SO & $\begin{array}{l}1.264 * * \\
(2.12)\end{array}$ & $\begin{array}{l}1.402 * * \\
(2.38)\end{array}$ & $\begin{array}{l}1.471 * * \\
(2.38)\end{array}$ & $\begin{array}{l}1.737 \text { *** } \\
(2.74)\end{array}$ & $\begin{array}{l}1.864 * * * \\
(2.83)\end{array}$ & $\begin{array}{l}0.600^{*} \\
(1.82)\end{array}$ \\
\hline High SO & $\begin{array}{l}1.158 * * \\
(2.03)\end{array}$ & $\begin{array}{l}1.279 * * \\
(2.31)\end{array}$ & $\begin{array}{l}1.607 * * * \\
(2.70)\end{array}$ & $\begin{array}{l}1.853 \text { *** } \\
(2.97)\end{array}$ & $\begin{array}{l}1.740 * * * \\
(2.77)\end{array}$ & $\begin{array}{l}0.583 \\
(1.60)\end{array}$ \\
\hline \multicolumn{7}{|l|}{ Large } \\
\hline Low SO & $\begin{array}{l}0.050 \\
(0.13)\end{array}$ & $\begin{array}{l}0.045 \\
(0.12)\end{array}$ & $\begin{array}{l}0.321 \\
(0.87)\end{array}$ & $\begin{array}{l}0.270 \\
(0.68)\end{array}$ & $\begin{array}{l}0.322 \\
(0.81)\end{array}$ & $\begin{array}{l}0.271 \\
(1.26)\end{array}$ \\
\hline High SO & $\begin{array}{l}0.333 \\
(0.87)\end{array}$ & $\begin{array}{l}0.174 \\
(0.54)\end{array}$ & $\begin{array}{l}0.101 \\
(0.32)\end{array}$ & $\begin{array}{l}0.172 \\
(0.47)\end{array}$ & $\begin{array}{l}0.241 \\
(0.65)\end{array}$ & $\begin{array}{l}-0.092 \\
(-0.21)\end{array}$ \\
\hline \multicolumn{7}{|c|}{ Panel B Default risk effect controlled for Size and SOE } \\
\hline Non-SOEs & $\begin{array}{l}0.986 * \\
(1.81)\end{array}$ & $\begin{array}{l}1.281 * * \\
(2.35)\end{array}$ & $\begin{array}{l}1.489 * * \\
(2.58)\end{array}$ & $\begin{array}{l}1.835^{\text {*** }} \\
(2.99)\end{array}$ & $\begin{array}{l}1.790 * * * \\
(2.85)\end{array}$ & $\begin{array}{l}0.803^{* *} \\
(2.58)\end{array}$ \\
\hline SOEs & $\begin{array}{l}1.331 * * \\
(2.18)\end{array}$ & $\begin{array}{l}1.330 * * \\
(2.16)\end{array}$ & $\begin{array}{l}1.475^{* *} \\
(2.34)\end{array}$ & $\begin{array}{l}1.801 * * * \\
(2.75)\end{array}$ & $\begin{array}{l}1.750 * * * \\
(2.61)\end{array}$ & $\begin{array}{l}0.420 \\
(1.29)\end{array}$ \\
\hline \multicolumn{7}{|l|}{ Large } \\
\hline Non-SOEs & $\begin{array}{l}0.143 \\
(0.32)\end{array}$ & $\begin{array}{l}0.312 \\
(0.73)\end{array}$ & $\begin{array}{l}0.179 \\
(0.40)\end{array}$ & $\begin{array}{l}0.341 \\
(0.74)\end{array}$ & $\begin{array}{l}0.552 \\
(1.21)\end{array}$ & $\begin{array}{l}0.408 \\
(0.88)\end{array}$ \\
\hline SOEs & $\begin{array}{l}0.171 \\
(0.48)\end{array}$ & $\begin{array}{l}0.177 \\
(0.59)\end{array}$ & $\begin{array}{l}0.101 \\
(0.31)\end{array}$ & $\begin{array}{l}0.211 \\
(0.59)\end{array}$ & $\begin{array}{l}0.179 \\
(0.52)\end{array}$ & $\begin{array}{l}0.008 \\
(0.02)\end{array}$ \\
\hline
\end{tabular}

This table represents monthly equal-weighted (EW) average portfolio alphas by triple sorting on market capitalization (SIZE), state-ownership (SO/SOE) and default risk (DLI). The sample period is from January 2003 to December 2015. At the end of each month, firms are sorted independently based on their market capitalization (SIZE) and state-ownership (SO/SOE). And then for each SIZE/SO or SIZE/SOE portfolio, they are dependently sorted by default risk (DLI) into quintiles. The portfolios are rebalanced monthly. The corresponding t-statistics are adjusted using the heteroscedasticity-consistent standard errors of Newey and West (1987)

$*$, **, and $* * *$ denote statistical significant level at 10,5 and $1 \%$, respectively 


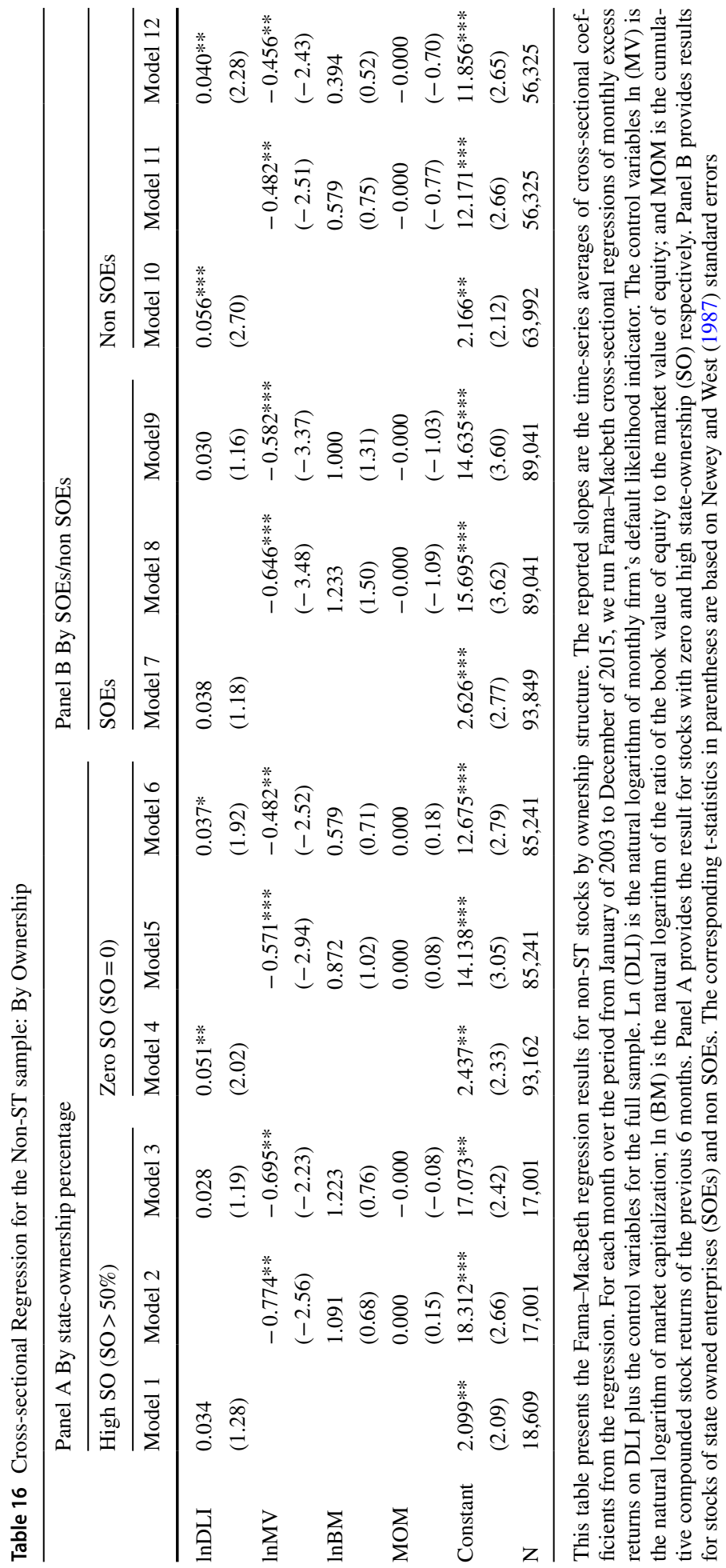




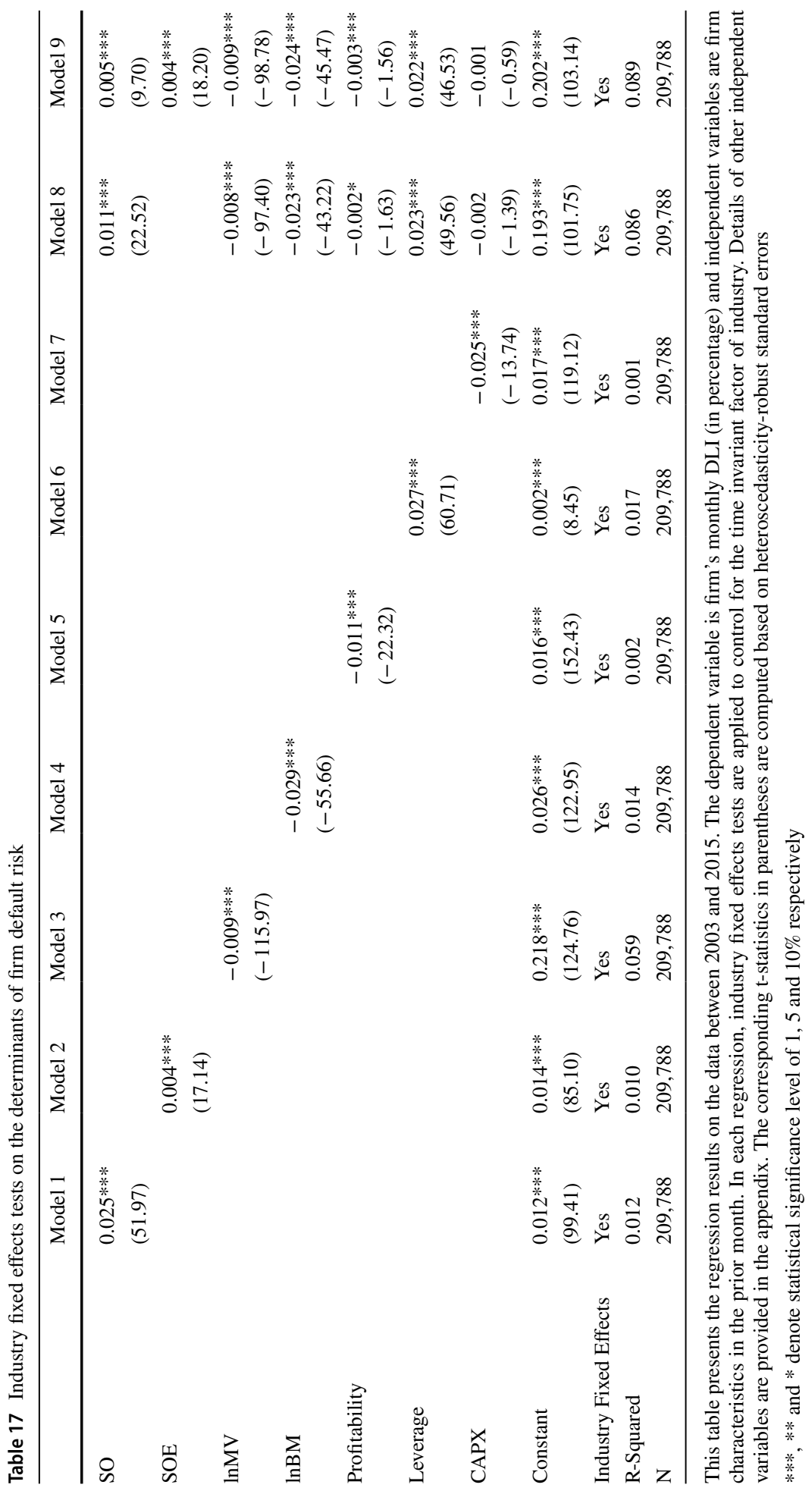




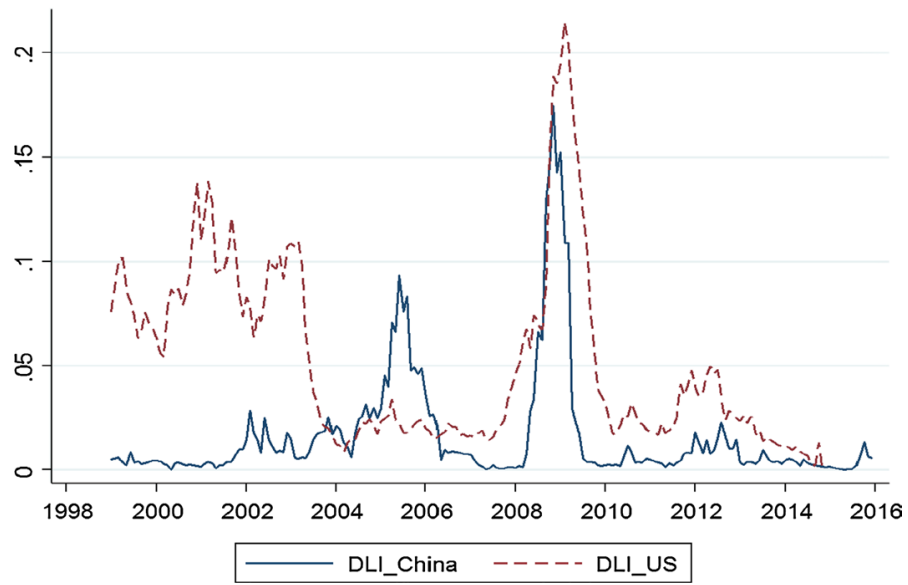

Fig. 4 Historical default likelihood indicator of Chinese and US listed firms. This figure plots the historical default probilitie (DLI) of Chinese and US Listed Firms from 1999 to 2015. The China sample includes all nonfinancial A-shares listed on Shanghai and Shenzhen Stock Exchange, and the US sample includes stocks of nonfinancial firms listed on NYSE, AMEX and NASDAQ exchange. DLI plotted in this figure is the arithmetic average of default likelihood across stocks in each month

\section{Appendix 2}

\section{Estimation of default likelihood indicators (DLIs) using the iterative procedure}

Firstly, for each stock in our sample, we estimate the volatility of a firm's equity, denoted as $\sigma_{E}$, by calculating the standard deviation of the daily returns on the stock over the past 12-month. To estimate the volatility of assets $\sigma_{A}$, we treat $\sigma_{E}$ as the initial value of equity volatility in an iterative procedure. Specifically, we define an interval based on the market value and the book value of the company's debt to extract the root from the equations.

Then, each $\sigma_{A}$ is used as the initial value of volatility for the next iteration procedure. This procedure is repeated for $n$ times until the adjacent values of $\sigma_{A}$ from the two iterations converge differ from each other by less than 0.0001 . We restrict the maximum number of iterations to 1000, but in practice, for the majority of sample firms, it takes less than 1000 iterations to reach convergence.

After that, we employ the Black-Scholes formula to extract the daily value of assets $V_{A t}$ for each trading day during the past 12 -month. Then the drift $\mu$ is computed as the mean of the log returns of $V_{A t}$.

Finally, we calculate monthly DLI for each stock using the estimated values of $\mu, \sigma_{A}$ together with the values of the firm's debt and assets.

\section{References}

Agarwal V, Taffler R (2008) Comparing the performance of market-based and accounting-based bankruptcy prediction models. J Bank Finance 32(8):1541-1551

Allen F, Qian J, Qian M (2005) Law, finance, and economic growth in China. J Financ Econ 77(1):57-116 
Altman EI (1968) Financial ratios, discriminant analysis and the prediction of corporate bankruptcy. J Finance 23(4):589-609

Altman EI, Iwanicz-Drozdowska M, Laitinen EK, Suvas A (2017) Financial distress prediction in an international context: a review and empirical analysis of altman's z-score model. J Int Financ Manag Acc 28(2):131-171

Avramov D, Chordia T, Jostova G, Philipov A (2009) Credit ratings and the cross-section of stock returns. J Financ Mark 12(3):469-499

Ben-Nasr H, Boubakri N, Cosset JC (2012) The political determinants of the cost of equity: evidence from newly privatized firms. J Account Res 50(3):605-646

Bharath ST, Shumway T (2008) Forecasting default with the Merton distance to default model. Rev Financ Stud 21(3):1339-1369

Bhattacharjee A, Han J (2014) Financial distress of Chinese firms: microeconomic, macroeconomic and institutional influences. China Econ Rev 30(C):244-262

Black F, Scholes M (1973) The pricing of options and corporate liabilities. J Polit Econ 81(3):637-654

Boubakri N, Guedhami O, Mishra D, Saffar W (2012) Political connections and the cost of equity capital. J Corp Finance 18(3):541-559

Campbell JY, Hilscher J, Szilagyi J (2008) In search of distress risk. J Finance 63(6):2899-2939

Chava S, Purnanandam A (2010) Is default risk negatively related to stock returns? Rev Financ Stud 23(6):2523-2559

Chen J, Hill P (2013) The impact of diverse measures of default risk on UK stock returns. J Bank Finance 37(12):5118-5131

Chen X, Kim KA, Yao T, Yu T (2010) On the predictability of Chinese stock returns. Pac Basin Finance J 18(4):403-425

Crosbie P, Bohn J (2003) Modeling default risk. https://business.illinois.edu/gpennacc/MoodysKMV.pdf. Accessed 15 June 2018

Cull R, Xu LC (2003) Who gets credit? The behavior of bureaucrats and state banks in allocating credit to Chinese state-owned enterprises. J Dev Econ 71(2):533-559

Cull R, Xu LC (2005) Institutions, ownership, and finance: the determinants of profit reinvestment among Chinese firms. J Financ Econ 77(1):117-146

Cull R, Li W, Sun B, Xu LC (2015) Government connections and financial constraints: evidence from a large representative sample of Chinese firms. J Corp Finance 32:271-294

Deng Y, Morck R, Wu J, Yeung B (2014) China's pseudo-monetary policy. Rev Finance 19(1):55-93

Dichev ID (1998) Is the risk of bankruptcy a systematic risk? J Finance 53(3):1131-1147

Du M, Boateng A, Newton D (2016) The impact of state ownership, formal institutions and resource seeking on acquirers' returns of Chinese M\&A. Rev Quant Finance Acc 47(1):159-178

Duan J-C, Sun J, Wang T (2012) Multiperiod corporate default prediction-a forward intensity approach. J Econ 170(1):191-209

Faccio M (2010) Differences between politically connected and nonconnected firms: a cross-country analysis. Financ Manag 39(3):905-928

Faccio M, Masulis RW, McConnell J (2006) Political connections and corporate bailouts. J Finance 61(6):2597-2635

Fama EF, French KR (1992) The cross-section of expected stock returns. J Finance 47(2):427-465

Fama EF, French KR (1993) Common risk factors in the returns on stocks and bonds. J Financ Econ 33(1):3-56

Fama EF, French KR (2008) Dissecting anomalies. J Finance 63(4):1653-1678

Fama EF, MacBeth JD (1973) Risk, return, and equilibrium: empirical tests. J Polit Econ 81(3):607-636

Fan JP, Huang J, Zhu N (2013) Institutions, ownership structures, and distress resolution in China. J Corp Finance 23:71-87

Fawcett T (2006) An introduction to ROC analysis. Pattern Recognit Lett 27(8):861-874

Filipe SF, Grammatikos T, Michala D (2016) Pricing default risk: the good, the bad, and the anomaly. J Financ Stab 26:190-213

Garlappi L, Yan H (2011) Financial distress and the cross-section of equity returns. J Finance 66(3):789-822

Garlappi L, Shu T, Yan H (2008) Default risk, shareholder advantage, and stock returns. Rev Financ Stud 21(6):2743-2778

Gharghori P, Chan H, Faff R (2006) Investigating the performance of alternative default-risk models: option-based versus accounting-based approaches. Aust J Manag 31(2):207-234

Gharghori P, Chan H, Faff R (2009) Default risk and equity returns: Australian evidence. Pac Basin Finance J 17(5):580-593

Groenewold N, Tang SHK, Wu Y (2003) The efficiency of the Chinese stock market and the role of the banks. J Asian Econ 14(4):593-609 
Hackbarth D, Miao J, Morellec E (2006) Capital structure, credit risk, and macroeconomic conditions. J Financ Econ 82(3):519-550

Hillegeist SA, Keating EK, Cram DP, Lundstedt KG (2004) Assessing the probability of bankruptcy. Rev Acc Stud 9(1):5-34

Hilliard J, Zhang H (2015) Size and price-to-book effects: evidence from the Chinese stock markets. Pac Basin Finance J 32:40-55

Hu XG, Can C, Yuan S, Jiang W (2018) Fama-French in China: size and value factors in Chinese stock returns. Int Rev Finance. https://doi.org/10.1111/irfi.12177

Huang W (2016) Tunneling through related-party loan guarantees: evidence from a quasi-experiment in China. Rev Quant Financ Acc 47(3):857-884

Huang F, He Y (2010) Enactment of default point in KMV model on CMBC, SPDB, CMB, Huaxia Bank and SDB. Int J Financ Res 1(1):30-36

Law D, Roache S (2015) Assessing default risks for Chinese firms: a lost cause? http://www.imf.org/exter $\mathrm{nal} / \mathrm{pubs} / \mathrm{ft} / \mathrm{wp} / 2015 / \mathrm{wp} 15140 . p d f$. Accessed 7 June 2018

Lee W, Wang L (2017) Do political connections affect stock price crash risk? Firm-level evidence from China. Rev Quant Financ Acc 48(3):643-676

Lehkonen H (2014) Stock market integration and the global financial crisis. Rev Finance 19(5):2039-2094

Leland H (2004) Predictions of expected default frequencies in structural models of debt. J Invest Manag 2:5-20

Liao L, Liu B, Wang H (2014) China's secondary privatization: perspectives from the split-share structure reform. J Financ Econ 113(3):500-518

Lin J, Wang M, Cai L (2012) Are the Fama-French factors good proxies for latent risk factors? Evidence from the data of SHSE in China. Econ Lett 116(2):265-268

Löffler G (2013) Can rating agencies look through the cycle? Rev Quant Financ Acc 40(4):623-646

Lu Z, Zhu J, Zhang W (2012) Bank discrimination, holding bank ownership, and economic consequences: evidence from China. J Bank Finance 36(2):341-354

Merton RC (1974) On the pricing of corporate debt: the risk structure of interest rates. J Finance 29(2):449-470

Morelli D (2012) Security returns, beta, size, and book-to-market equity: evidence from the Shanghai A-share market. Rev Quant Financ Acc 38(1):47-60

Newey WK, West KD (1987) Hypothesis testing with efficient method of moments estimation. Int Econ Rev 28(3):777-787

Ohlson JA (1980) Financial ratios and the probabilistic prediction of bankruptcy. J Account Res 18(1):109-131

Petersen MA (2009) Estimating standard errors in finance panel data sets: comparing approaches. Rev Financ Stud 22(1):435-480

Qiao Z, Li Y, Wong W-K (2008) Policy change and lead-lag relations among China's segmented stock markets. J Multinatl Financ Manag 18(3):276-289

Sapienza P (2004) The effects of government ownership on bank lending. J Financ Econ 72(2):357-384

Song Z, Storesletten K, Zilibotti F (2011) Growing like china. Am Econ Rev 101(1):196-233

Tudela M, Young G (2005) A Merton-model approach to assessing the default risk of UK public companies. Int J Theor Appl Finance 8(6):737-761

Vassalou M, Xing Y (2004) Default risk in equity returns. J Finance 59(2):831-868

Xu M, Zhang C (2009) Bankruptcy prediction: the case of Japanese listed companies. Rev Acc Stud 14(4):534-558

Yang Z, Hou W, Qian X (2015) The Split-Share-Structure Reform in China: Past, Procedure, and Impact. In: Cumming D, Firth M, Hou W, Lee E (eds) Sustainable Entrepreneurship in China. Palgrave Macmillan, New York, pp 159-177

Zeng Y, McLaren J (2015) The impact of large public sales of Government assets: empirical evidence from the Chinese stock markets on a gradual and offer-to-get approach. Rev Quant Financ Acc 45(1):137-173 